\title{
Molecular genetics of prostate cancer
}

\author{
Cory Abate-Shen ${ }^{1,2,4,5}$ and Michael M. Shen ${ }^{1,3-5}$ \\ ${ }^{1}$ Center for Advanced Biotechnology and Medicine, ${ }^{2}$ Department of Neuroscience and Cell Biology, ${ }^{3}$ Department \\ of Pediatrics, ${ }^{4}$ Dean and Betty Gallo Prostate Cancer Center, Cancer Institute of New Jersey, UMDNJ-Robert Wood \\ Johnson Medical School, Piscataway, New Jersey 08854, USA
}

Prostate cancer afflicts one man in nine over the age of 65 and represents the most frequently diagnosed cancer in American men (Coffey 1993). Early detection through serum testing for prostate specific antigen (PSA) and improved procedures for surgical intervention and radiation therapy have significantly reduced the number of fatalities; however, there is still no effective cure for men with advanced disease. Therefore, much research has been dedicated to identifying prognostic markers that distinguish indolent versus aggressive forms of prostate cancer. In contrast, significantly less research has been devoted to understanding the molecular mechanisms that underlie normal prostate growth and development or cancer initiation and progression.

In this review, we address recent progress toward the central objectives of understanding parameters of normal versus abnormal prostatic development and of elucidating a molecular pathway for prostate cancer progression. We focus on key regulatory molecules that have been implicated by analysis of patterns of allelic loss in human prostate cancers and/or by reverse genetic approaches in the mouse.

\section{Characteristic features of prostate cancer}

Most prostate tumors are adenocarcinomas, sharing numerous common features with other prevalent epithelial cancers, such as breast and colon cancer. Here, we introduce certain salient aspects of prostate cancer that are relevant for investigation of the disease process.

\section{Correlation with aging}

A distinguishing feature of prostate cancer is its intimate association with aging; indeed, aging is the single most significant risk factor for prostate cancer. Although preneoplastic lesions known as prostatic intraepithelial neoplasia (PIN) can be found in men in their twenties and are fairly common in men by their fifties (Sakr et al.

${ }^{5}$ Corresponding authors.

E-MAIL abate@cabm.rutgers.edu; FAX (732) 235-5789.

E-MAIL mshen@cabm.rutgers.edu; FAX (732) 235-5373.

Article and publication are at www.genesdev.org/cgi/doi/10.1101/ gad.819500.
1993), clinically detectable prostate cancer is not generally manifest until the age of 60 or 70 . Furthermore, the occurrence of precancerous lesions is significantly more prevalent $(\sim 1$ in $3 \mathrm{men})$ than the incidence of carcinoma ( 1 in 9 men). Therefore, whereas the morphological changes associated with initiation are relatively common and occur early in life, progression to invasive carcinoma is a significantly less common event that occurs in a more limited population as a consequence of aging.

\section{Environmental factors}

The incidence of prostate cancer in the United States is significantly higher than in most other countries, particularly Asian countries, even though the incidence of histological pre-neoplastic lesions has been reported to be similar worldwide (Dhom 1983). Dietary and environmental factors have therefore been presumed to play a key role in prostate carcinogenesis (Carter et al. 1990a), similar to their role in other common epithelial cancers. Recent evidence, however, has thrown into question whether there actually are differences in the relative incidence of preneoplastic lesions in Asian versus American men (Miller 2000).

\section{Familial inheritance}

Hereditary factors account for a relatively small percentage $(-10 \%)$ of prostate cancers and are generally associated with early onset disease (Cannon et al. 1982; Carter et al. 1992, 1993). To date, two familial susceptibility loci have been mapped to the $\mathrm{X}$ chromosome and to a region of chromosome 1q (Smith et al. 1996; Xu et al. 1998), although the respective candidate genes have not yet been identified. In addition, several studies have identified a statistical association between breast and prostate cancer (Thiessen 1974; Anderson and Badzioch 1992; Tulinius et al. 1992), but the molecular basis for such a link is unresolved.

\section{Role of steroid hormones}

Steroid hormone receptor signaling plays a pivotal role in all stages of prostate carcinogenesis. In particular, there is a characteristic age-related decrease in the ratio of an- 
drogens to estrogens in men, which may represent a contributing factor in prostate cancer initiation (Mawhinney and Neubauer 1979; Dai et al. 1981; Prehn 1999). In addition, the transition to androgen independence that is a hallmark of advanced prostate cancer has been a focus of numerous investigations.

\section{Heterogeneity and multifocality}

The heterogeneous and multifocal nature of prostate cancer lesions poses significant difficulties for researchers. With regard to heterogeneity, histological inspection of prostate cancer tissue typically reveals a juxtaposition of benign glands, preneoplastic (PIN) foci, and neoplastic foci of varying severity (Fig. 1). To account for this heterogeneity, Gleason proposed a grading system that is now the predominant system used by pathologists, since it is an excellent prognostic indicator. In this system, a score is given based on the sum of the two most prevalent grades of neoplastic foci (e.g., $3+3 ; 3+4$ ); a higher Gleason grade indicates a more advanced carcinoma (Gleason 1992).

With regard to multifocality, individual neoplastic le- sions within a given section of prostate cancer tissue have been described as genetically distinct (nonclonal), even those in close proximity (e.g., Bostwick et al. 1998; Macintosh et al. 1998). This observation suggests that multiple neoplastic foci may emerge and evolve independently, which has significant implications for the molecular mechanisms of disease progression.

From a practical standpoint, the heterogeneity and multifocality of prostatic lesions, combined with the relatively small size of the prostate, make it difficult to obtain reasonably homogeneous material in sufficient quantities for molecular analysis. These factors represent significant limitations in identifying regulatory genes associated with prostate carcinogenesis, as well as in defining a molecular pathway for the initiation and progression of prostate cancer. In recent years, these difficulties have been partially circumvented by microdissection and laser-capture microscopy approaches that facilitate analysis of individual neoplastic foci (EmmertBuck et al. 1995, 1996; Macintosh et al. 1998), and by cell-sorting approaches that permit the isolation of relatively pure populations of carcinoma cells (Liu et al. 1997, 1999).
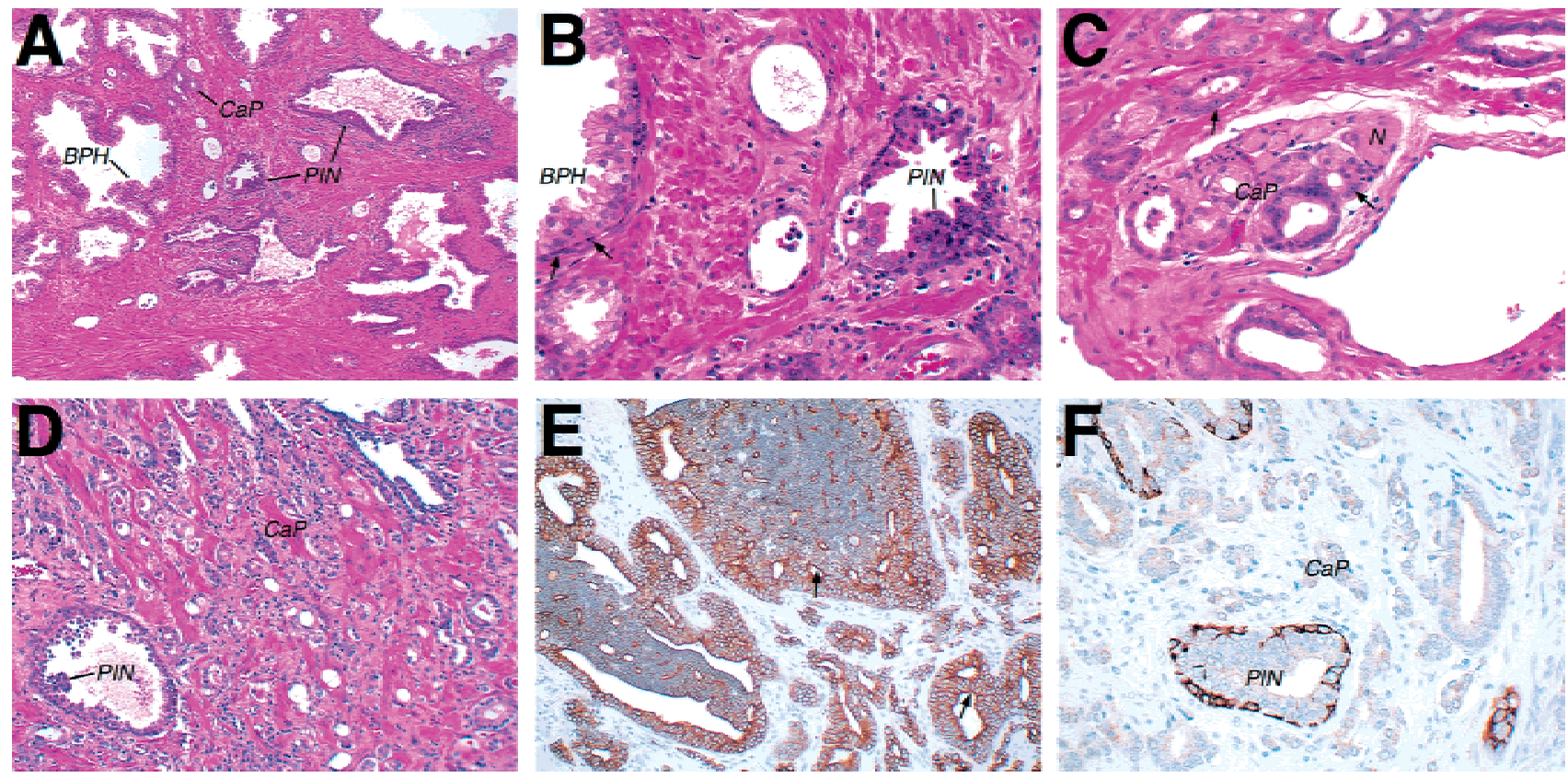

Figure 1. Histology of human prostate tissue. Panels $A-D$ depict hematoxylin-eosin stains, while panels $E$ and $F$ show immunohistochemical analyses. $(A)$ Low-power view showing the characteristic heterogeneity of prostate tissue, with this region containing a combination of BPH, PIN, and well-differentiated adenocarcinoma (CaP). (B) High-power view of a region in panel $A$, showing details of BPH and PIN. The region of BPH has ducts surrounded by basal cells (arrows), which are not found in the region of PIN. The area of PIN shows a transition within the same duct between normal and atypical hyperchromatic cells that contain larger nuclei with prominent nucleoli. $(C)$ High-power view showing a nearby area of human prostate with a well-differentiated adenocarcinoma that is invading the peri-neural space ( $\mathrm{N}$ marks the position of the nerve fiber). Note that the carcinoma cells have large nuclei with very prominent nucleoli (arrows). (D) View of a different prostate sample with high-grade PIN and a mixture of Gleason grade 4 and 5 carcinoma in the rest of the field. (E) Immunohistochemical staining of PIN and carcinoma using anti-cytokeratin 8 , which marks all of the epithelial cells. These PIN lesions have a cribiform pattern (arrows), but are still within the confines of a prostatic duct. ( $F$ ) Immunohistochemical staining of a tissue section containing both PIN and carcinoma using anti-cytokeratin 14, which marks the basal cells. Notably, the PIN displays inconsistent staining, whereas the carcinoma has no staining. All panels and interpretations were generously provided by Dr. Regina Gandour-Edwards and Dr. Robert Cardiff (School of Medicine, University of California-Davis, Davis, CA). 


\section{Limited number of established cell lines}

Prostate cancer research has also been hampered by difficulties in generating permanent cell lines for in vitro studies. This limitation is undoubtedly related to the inherently slow growth of most prostate tumors and the low proliferation rate of the normal prostatic epithelium (e.g., Isaacs and Coffey 1989; Berges et al. 1995). Despite numerous attempts to obtain cell lines (discussed in Bright et al. 1997; Navone et al. 1999), only a handful of human prostate lines have been generated, of which the most commonly used (LNCaP, PC3, DU145, and TSUPr1) were isolated from metastatic lesions rather than primary tumors. This restriction implies that numerous conclusions in the literature are based on studies of a small repertoire of cell lines, even though the relevance of these cell lines for prostate carcinogenesis in vivo is uncertain.

\section{Anatomy and development of the prostate}

\section{Comparison of the human and the murine prostate}

The prostate gland surrounds the urethra at the base of the bladder and functions by contributing secretory proteins to the seminal fluid. Found exclusively in mammals, the prostate is not required for viability or even basal levels of fertility; therefore, its primary significance stems from its relevance for human disease. Indeed, it is intriguing to note that malignant prostatic tumors are among the most common neoplasia in men, whereas other ductal organs of the male urogenital system, such as the seminal vesicles and bulbourethral (Cowper's) glands, are virtually immune to neoplasia.

In adult humans, the prostate is a small acorn-shaped tissue, with ductal-acinar histology, that lacks discernible lobular organization (Fig. 2A). In his classic work, McNeal defined three distinct morphological regions within the human prostate: the peripheral zone, the tran- sition zone, and the central zone (McNeal 1969, 1988). The significance of this architecture is based upon the relationship of these zones to prostatic disease. Benign prostatic hyperplasia (BPH), a nonmalignant overgrowth that is fairly common among aging men, occurs mainly in the transition zone, and prostate carcinoma arises primarily in the peripheral zone.

In contrast with humans, the rodent prostate gland consists of four distinct lobes: anterior (also known as the coagulating gland), dorsal and lateral (collectively referred to as the dorsolateral lobe), and ventral (Fig. 2B). These lobes are arranged circumferentially around the bladder and display characteristic patterns of ductal branching and secretory protein production (Sugimura et al. 1986; Hayashi et al. 1991). There is no clear analogy between the lobular structure of the rodent prostate and the zonal architecture of the human prostate; indeed, although several studies assert that the dorsolateral lobe is most similar to the human peripheral zone, the evidence supporting this assertion is primarily descriptive. Notably, the dissimilar anatomy and morphology of the rodent prostate, together with the absence of spontaneous prostate cancer in laboratory rodents, has led to concerns about the relevance of rodent models for human prostate disease. Recent studies, however, strongly support the validity of rodent models for prostate cancer, as discussed below.

\section{Formation and morphogenesis of the prostate}

Formation of the prostate occurs during embryogenesis through epithelial budding from the urogenital sinus, a hindgut derivative that is of endodermal origin. During midgestation, the primitive urogenital sinus is separated from the terminal region of the hindgut through the division of the cloaca by the urorectal septum. The most rostral region (vesiculo-urethral part) of the primitive urogenital sinus forms the urinary bladder, whereas the
A

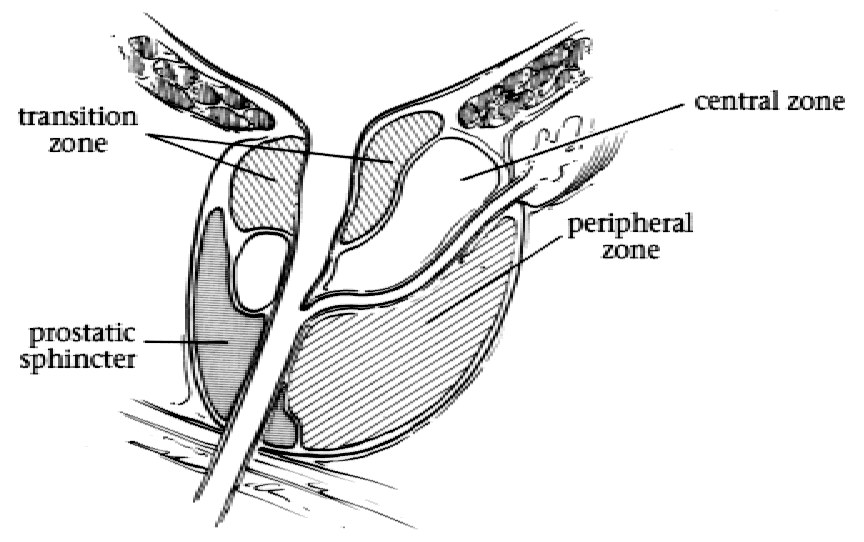

Adult human (sagittal section)
B

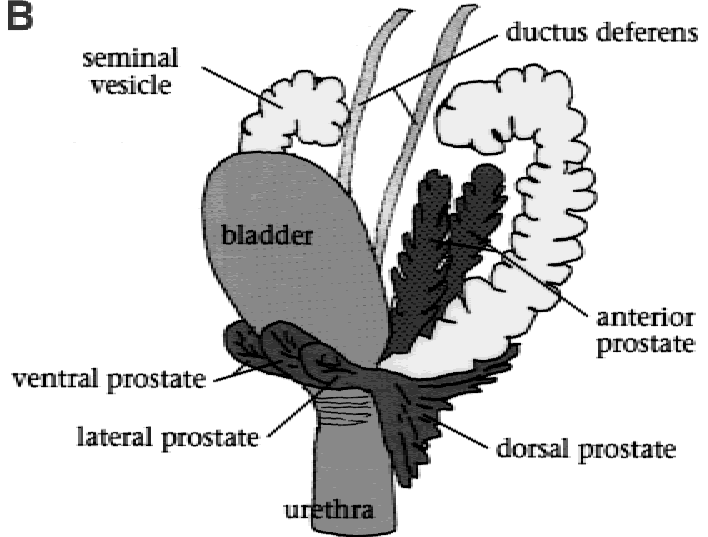

Adult mouse (lateral view)

Figure 2. Schematic illustration of the anatomy of the human $(A)$ and mouse $(B)$ prostate (adapted from McNeal 1969 and Cunha et al. 1987, respectively). 
most caudal region (phallic part) forms the penile urethra. The prostate gland originates from the intermediate region, known as the pelvic part (generally referred to as the urogenital sinus). In the mouse, the prostatic buds first emerge at the rostral end of the urogenital sinus at approximately 17.5 days of gestation, toward the end of pregnancy. Subsequently, the prostatic epithelial buds undergo extensive ductal outgrowth and branching into the surrounding mesenchyme during the first three weeks of postnatal development (Sugimura et al. 1986; Timms et al. 1994). Notably, although ductal morphogenesis is androgen dependent, the early postnatal period is marked by low levels of circulating androgens (Barkley and Goldman 1977; Jean-Faucher et al. 1978). Although the overall process is similar in humans, the time course of prostate maturation differs significantly, since ductal morphogenesis largely occurs in response to high levels of androgen stimulation during puberty.

The analysis of the Nkx3.1 homeobox gene has recently provided insights into the earliest stages of prostate formation in the mouse (Sciavolino et al. 1997; Bhatia-Gaur et al. 1999). Within the urogenital system, $N k \times 3.1$ expression is first detected in the lateral aspects of the urogenital sinus epithelium prior to prostate formation, and subsequently marks all stages of prostate development. Notably, Nkx3.1 expression precedes formation of the prostatic buds by two days, and appears to correspond to the regions where prostatic buds will emerge, suggesting that regions of the urogenital sinus epithelium may have a differential capacity to form prostate (Bhatia-Gaur et al. 1999). This idea is distinct from the previous view that the mesenchyme is solely responsible for inducing a passive epithelium.

The identification of additional regulatory genes and pathways expressed during prostate development represents an important avenue of future research. Current candidates for such regulatory genes include components of the Sonic hedgehog and BMP signaling pathways (Table 1; Dunn et al. 1997; Podlasek et al. 1999). Given that carcinogenesis often involves deregulation of developmental regulatory genes, elucidation of the molecular pathways of prostate development should provide fresh insights into prostate cancer.

\section{Epithelial-mesenchymal interactions in prostate development}

As with many other tissues, prostate formation is initiated as a consequence of interactions between epithelial and mesenchymal tissues. The role of epithelial-mesenchymal interactions in prostate formation has been defined through elegant tissue recombination studies performed by Cunha and colleagues (Cunha et al. 1987; Cunha 1996; Hayward et al. 1997). These tissue recombinations employ dissection and enzymatic isolation of epithelium and mesenchyme from embryonic urogenital sinus and/or from other tissues, which are then recombined in vitro and transplanted under the kidney capsule of adult male nude mouse hosts. The formation of prostate tissue in these recombinants can subsequently be assessed by their histological appearance and by production of prostatic secretory proteins.

These tissue recombination studies have led to the following principal conclusions:

1. Prostatic differentiation requires both epithelial and mesenchymal components; in the absence of either, mature cell types fail to differentiate.

2. Specificity for the mesenchymal component is relatively stringent, because prostate will only form using mesenchyme from embryonic urogenital sinus (and under certain conditions, from seminal vesicle).

3. Specificity for the epithelial component is relatively broad, because a wide range of epithelia of endodermal origin, including those from differentiated male or female adult tissues, can form prostate when combined with urogenital sinus mesenchyme.

4. During prostate development, androgens initially act on the mesenchyme, because prostate does not form when urogenital sinus mesenchyme that is defective in androgen receptor (from a Testicular-feminization $[T f m]$ mutant) is combined with wild-type urogenital sinus epithelium. Subsequently, androgens act on the epithelium, for urogenital sinus epithelium defective in androgen receptor combined with wild-type mesenchyme forms prostatic ducts that lack production of prostatic secretory proteins. These results indicate that androgen signaling is required in the mesenchyme to produce signals for prostate induction and growth, and later in the epithelium for the secretory function of differentiated cell types.

5. Human epithelium and rodent mesenchyme (and vice versa) can be recombined to form prostate, supporting the validity of rodent prostate as a model for the human gland.

Because interactions between the epithelial and stromal components are essential for all stages of normal prostate growth and development, it is likely that aberrant interactions play a significant role in carcinoma. Although neoplastic foci arise in the epithelial compartment, the role of the stromal compartment in carcinogenesis has been relatively neglected. Notably, however, tissue recombination experiments have suggested that aberrant growth factor signaling from stromal components plays an integral role in cancer progression (Hayward et al. 1997; Olumi et al. 1999). The signals that mediate such mesenchymal-epithelial interactions in carcinogenesis have not been identified, but may include members of the fibroblast growth factor (FGF) and transforming growth factor- $\beta$ (TGF $\beta$ ) families (Cunha 1996; Djakiew 2000).

\section{Prostatic epithelial cell types and their relationship to carcinogenesis}

Within the prostatic epithelium, there are at least three distinct cell types that can be distinguished by their morphological characteristics, functional significance, and relevance for carcinogenesis (Fig. 3). The predominant cell type is the secretory luminal cell, a differentiated 
Table 1. Candidate regulatory genes for prostate development and carcinogenesis

\begin{tabular}{|c|c|c|c|}
\hline Gene & Product & Mouse and human phenotype & References \\
\hline \multicolumn{4}{|l|}{ Normal development } \\
\hline Androgen receptor & $\begin{array}{l}\text { Nuclear hormone } \\
\text { receptor }\end{array}$ & $\begin{array}{l}\text { Required in mesenchyme for initial formation } \\
\text { of prostatic buds, and subsequently in } \\
\text { epithelium for secretory protein production }\end{array}$ & $\begin{array}{l}\text { (Cunha et al. 1987; Cunha et al., } \\
\text { in press) }\end{array}$ \\
\hline Nkx3.1 & $\begin{array}{l}\text { Homeodomain } \\
\text { transcription factor }\end{array}$ & $\begin{array}{l}\text { Expressed in prostatic regions of urogenital } \\
\text { sinus epithelium and in newly formed } \\
\text { prostatic buds; required for normal ductal } \\
\text { morphogenesis and production of secretory } \\
\text { proteins }\end{array}$ & (Bhatia-Gaur et al. 1999) \\
\hline Shh & $\begin{array}{l}\text { Secreted signaling } \\
\text { factor }\end{array}$ & $\begin{array}{l}\text { Expressed in urogenital sinus epithelium, } \\
\text { anti-Shh antibodies inhibit prostate } \\
\text { morphogenesis }\end{array}$ & (Podlasek et al. 1999) \\
\hline$B M P-4$ & $\begin{array}{l}\text { Secreted member of } \\
\text { TGF } \beta \text { superfamily }\end{array}$ & $\begin{array}{l}\text { Defective prostate morphogenesis in } \\
\text { heterozygous mice }\end{array}$ & (Dunn et al. 1997) \\
\hline FGF7 & Growth factor & $\begin{array}{l}\text { Stimulates prostatic growth in culture; mutant } \\
\text { mice do not display prostatic defects }\end{array}$ & (Cunha et al., in press) \\
\hline FGF10 & Growth factor & $\begin{array}{l}\text { Expression in prostate is androgen-regulated; } \\
\text { stimulates growth of prostate epithelium }\end{array}$ & (Cunha et al., in press) \\
\hline$T G F \beta 1$ & Growth factor & $\begin{array}{l}\text { Implicated as a regulator of androgen signaling; } \\
\text { mutant mice display defects in prostatic duct } \\
\text { formation }\end{array}$ & (Cunha et al., in press) \\
\hline HoxD13 & $\begin{array}{l}\text { Homeodomain } \\
\text { transcription factor }\end{array}$ & $\begin{array}{l}\text { Expressed in the developing and adult prostate; } \\
\text { mild defects in prostatic morphogenesis in } \\
\text { mutant mice }\end{array}$ & (Podlasek et al. 1997) \\
\hline \multicolumn{4}{|c|}{ Initiation and progression to carcinoma } \\
\hline NKX3.1 & $\begin{array}{l}\text { Homeodomain } \\
\text { transcription factor }\end{array}$ & $\begin{array}{l}\text { Prostatic epithelial hyperplasia and dysplasia } \\
\text { followed by PIN in aged heterozygous and } \\
\text { homozygous mutant mice; prostate-specific } \\
\text { expression in human and mouse adult } \\
\text { tissues; human gene maps to minimal } \\
\text { deleted region of } 8 \mathrm{p} 21 \text {, but not mutated in } \\
\text { human tumors }\end{array}$ & $\begin{array}{l}\text { (He et al. 1997; Voeller et al. } \\
\text { 1997; Bhatia-Gaur et al. 1999) }\end{array}$ \\
\hline PTEN & Lipid phosphatase & $\begin{array}{l}\text { Heterozygous mutant mice develop hyperplasia } \\
\text { and dysplasia of multiple tissues including } \\
\text { prostate; human gene maps to } 10 \mathrm{q} 23 \text {, but } \\
\text { status of mutations is unresolved }\end{array}$ & $\begin{array}{l}\text { (Li et al. 1997; Steck et al. 1997; } \\
\text { Di Cristofano et al. 1998; Dong } \\
\text { et al. 1998; Facher and Law } \\
\text { 1998; Feilotter et al. 1998; } \\
\text { Suzuki et al. 1998b; Vlietstra } \\
\text { et al. 1998; Wang et al. 1998; } \\
\text { Podsypanina et al. 1999) }\end{array}$ \\
\hline MXI1 & Transcription factor & $\begin{array}{l}\text { Relatively mild prostatic epithelial hyperplasia } \\
\text { and dysplasia in homozygous mutant mice; } \\
\text { human gene maps to 10q24, but is } \\
\text { infrequently mutated }\end{array}$ & $\begin{array}{l}\text { (Eagle et al. 1995; Kawamata et } \\
\text { al. 1996; Kuczyk et al. 1998; } \\
\text { Prochownik et al. 1998; } \\
\text { Schreiber-Agus et al. 1998) }\end{array}$ \\
\hline$R b$ & Cell-cycle regulator & $\begin{array}{l}\text { Homozygous mutant mice prone to } \\
\text { hyperplasia, dysplasia and carcinoma in } \\
\text { combined prostatic rescue and hormone } \\
\text { induction model; human gene maps to } 13 \mathrm{q} \\
\text { and functional studies suggest a critical role, } \\
\text { but it is infrequently mutated }\end{array}$ & $\begin{array}{l}\text { (Bookstein et al. 1990a; } \\
\text { Bookstein et al. 1990b; Sarkar } \\
\text { et al. 1992; Cooney et al. } \\
\text { 1996b; Melamed et al. 1997; Li } \\
\text { et al. 1998; Wang et al., in } \\
\text { press) }\end{array}$ \\
\hline p27 & Cell-cycle regulator & $\begin{array}{l}\text { Homozygous mutant mice develop hyperplasia } \\
\text { and dysplasia of multiple tissues including } \\
\text { prostate; loss of expression in human tumors } \\
\text { correlates with tumor grade }\end{array}$ & $\begin{array}{l}\text { (Fero et al. 1996; Kiyokawa et al. } \\
\text { 1996; Nakayama et al. 1996; } \\
\text { Guo et al. 1997; Cordon-Cardo } \\
\text { et al. 1998; Cote et al. 1998; } \\
\text { De Marzo et al. 1998a; Tsihlias } \\
\text { et al. 1998; Yang et al. 1998) }\end{array}$ \\
\hline p16 & Cell-cycle regulator & $\begin{array}{l}\text { Protein expression is up-regulated in } \\
\text { carcinoma, but mutations are infrequent; } \\
\text { limited information is currently available on } \\
\text { the prostate phenotype of mutant mice or on } \\
\text { the status of other INK family members }\end{array}$ & $\begin{array}{l}\text { (Chen et al. 1996; Tamimi et al. } \\
\text { 1996; Chi et al. 1997; } \\
\text { Gaddipati et al. 1997; Mangold } \\
\text { et al. 1997; Park et al. 1997; } \\
\text { Gu et al. 1998) }\end{array}$ \\
\hline
\end{tabular}


Table 1. (Continued)

\begin{tabular}{|c|c|c|c|}
\hline Gene & Product & Mouse and human phenotype & References \\
\hline Telomerase & Ribonucleoprotein & $\begin{array}{l}\text { Reduced telomere length and increased } \\
\text { telomerase activity found in PIN and } \\
\text { carcinoma }\end{array}$ & $\begin{array}{l}\text { (Sommerfeld et al. 1996; Zhang } \\
\text { et al. 1998) }\end{array}$ \\
\hline Myc & Transcription factor & $\begin{array}{l}\text { Amplified in some carcinomas; cooperates with } \\
R A S \text { to induce hyperplasia in tissue } \\
\text { recombinants }\end{array}$ & $\begin{array}{l}\text { (Thompson et al. 1989; Van Den } \\
\text { Berg et al. 1995; Bubendorf et } \\
\text { al. 1999) }\end{array}$ \\
\hline FGFs & Growth factors & $\begin{array}{l}\text { Several family members, including FGF7 and } \\
\text { FGF10, are implicated as regulators of } \\
\text { prostatic growth; altered FGF function } \\
\text { associated with progression in TRAMP mice }\end{array}$ & (Foster et al. 1998; Djakiew 2000) \\
\hline E-cadherin & Cell adhesion & $\begin{array}{l}\text { Reduced expression in PIN and carcinoma; loss } \\
\text { may be associated with poor prognosis }\end{array}$ & $\begin{array}{l}\text { (Umbas et al. 1992; Morton et al. } \\
\text { 1993; Umbas et al. 1994) }\end{array}$ \\
\hline$c-C A M$ & Cell adhesion & $\begin{array}{l}\text { Expression is reduced in PIN and lost in } \\
\text { carcinoma }\end{array}$ & (Kleinerman et al. 1995) \\
\hline Integrins & Cell interactions & $\begin{array}{l}\text { Reduced expression of specific family members } \\
\text { during cancer progression }\end{array}$ & (Cress et al. 1995) \\
\hline$c-M e t$ & $\begin{array}{l}\text { Tyrosine-kinase } \\
\text { receptor }\end{array}$ & $\begin{array}{l}\text { Overexpressed in PIN, carcinoma, and } \\
\text { metastasis }\end{array}$ & (Pisters et al. 1995) \\
\hline \multicolumn{4}{|c|}{ Advanced carcinoma and metastasis } \\
\hline Androgen receptor & $\begin{array}{l}\text { Nuclear hormone } \\
\text { receptor }\end{array}$ & $\begin{array}{l}\text { Expression maintained even in androgen- } \\
\text { independent tumors, although it is often } \\
\text { amplified or mutated }\end{array}$ & $\begin{array}{l}\text { (Bentel and Tilley 1996; Culig et } \\
\text { al. 1998; Koivisto et al. 1998) }\end{array}$ \\
\hline p53 & $\begin{array}{l}\text { Transcription/ } \\
\text { apoptotic regulator }\end{array}$ & $\begin{array}{l}\text { Mutation rate in is low in primary cancer; } \\
\text { frequently mutated in metastasis; } p 53 \\
\text { overexpression correlated with poor prognosis }\end{array}$ & $\begin{array}{l}\text { (Bookstein et al. 1993; Effert et } \\
\text { al. 1993; Navone et al. 1993; } \\
\text { Thomas et al. 1993; Aprikian } \\
\text { et al. 1994; Henke et al. 1994; } \\
\text { Voeller et al. 1994; Bauer et al. } \\
\text { 1995; Eastham et al. 1995; } \\
\text { Heidenberg et al. 1995; } \\
\text { Shurbaji et al. 1995; Moul et } \\
\text { al. 1996; Prendergast et al. } \\
\text { 1996; Matsushima et al. 1997; } \\
\text { Theodorescu et al. 1997; } \\
\text { Brewster et al. 1999; } \\
\text { Stackhouse et al. 1999) }\end{array}$ \\
\hline Bcl2 & Apoptotic regulator & $\begin{array}{l}\text { Overexpression confers resistance to apoptosis } \\
\text { in androgen-independent disease; key target } \\
\text { for clinical intervention }\end{array}$ & $\begin{array}{l}\text { (Colombel et al. 1993; Apakama } \\
\text { et al. 1996; Furuya et al. 1996; } \\
\text { McDonnell et al. 1997; } \\
\text { DiPaola and Aisner 1999) }\end{array}$ \\
\hline IGF1 & Growth factor & $\begin{array}{l}\text { Promotes growth of prostate epithelium; } \\
\text { elevated serum levels associated with cancer } \\
\text { risk; overexpression of IGF1 in TRAMP mice } \\
\text { associated with progression }\end{array}$ & $\begin{array}{l}\text { (Chan et al. 1998; Kaplan et al. } \\
\text { 1999; Djakiew 2000) }\end{array}$ \\
\hline$T G F \beta 1$ & Growth factor & $\begin{array}{l}\text { Negative regulator of prostate growth; shift to } \\
\text { autocrine regulation associated with } \\
\text { metastasis }\end{array}$ & (Djakiew 2000) \\
\hline$E G F / T G F \alpha$ & Growth factor & $\begin{array}{l}\text { Stimulates prostatic epithelial cell growth and } \\
\text { invasiveness; may provide a mechanism for } \\
\text { overcoming androgen-dependence }\end{array}$ & (Djakiew 2000) \\
\hline Ka1 & $\begin{array}{l}\text { Putative integral } \\
\text { membrane protein }\end{array}$ & $\begin{array}{l}\text { Shown to suppress metastases; protein } \\
\text { expression is down-regulated but is not } \\
\text { mutated }\end{array}$ & $\begin{array}{l}\text { (Dong et al. 1995; Dong et al. } \\
\text { 1996) }\end{array}$ \\
\hline
\end{tabular}

androgen-dependent cell that produces prostatic secretory proteins. At the molecular level, luminal cells are characterized by their expression of androgen receptor, as well as cytokeratins 8 and 18 and the cell surface marker CD57 (Brawer et al. 1985; Nagle et al. 1987; Ver- hagen et al. 1988; Sherwood et al. 1990; Liu et al. 1997). The second major epithelial cell type corresponds to the basal cells, which are found between the luminal cells and the underlying basement membrane, and which form a continuous layer in the human prostate, but not 


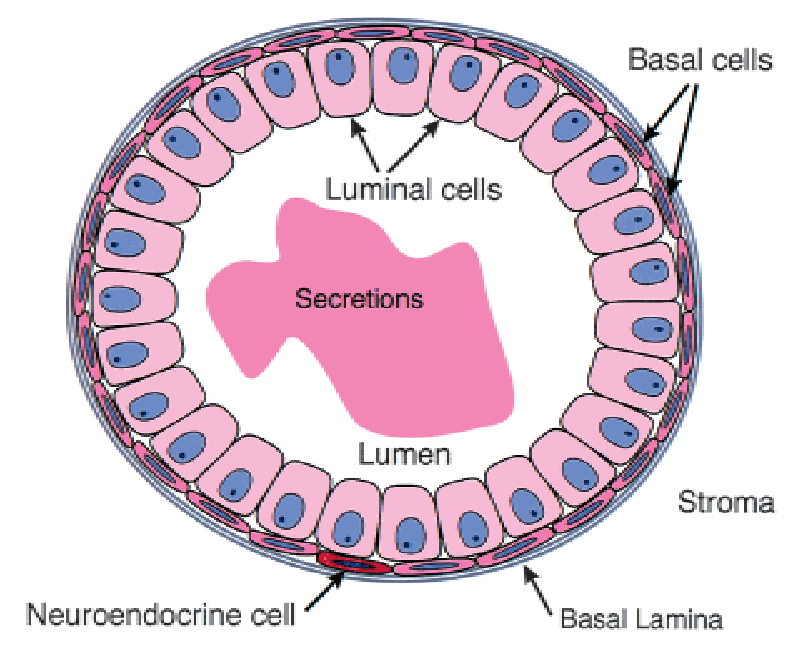

Figure 3. Schematic depiction of the cell types within a human prostatic duct. Note that the rare neuroendocrine cells are morphologically indistinguishable from basal cells.

in the mouse prostate. Basal cells express cytokeratins 5 and 14 as well as CD44 as well as low levels of androgen receptor (although this is controversial), but do not produce prostatic secretory proteins (Brawer et al. 1985; Nagle et al. 1987; Verhagen et al. 1988; Sherwood et al. 1990; Liu et al. 1997; Bui and Reiter 1998). Consistent with a possible stem cell function (see below), basal cells also express factors that protect from DNA damage, such as the free-radical scavenger Gst- $\pi$ and the anti-apoptotic gene Bcl2 (Bui and Reiter 1998; De Marzo et al. 1998b). Finally, the third prostatic epithelial cell type is the neuroendocrine cell, a minor population of uncertain embryological origin, which is believed to provide paracrine signals that support the growth of luminal cells /di Sant'Agnese 1992, 1998; Abrahamsson 1999|. Neuroendocrine cells are androgen-independent cells dispersed throughout the basal layer that express chromogranin A, serotonin, and various neuropeptides.

Early studies had raised the possibility that neuroendocrine cells are derived from the migratory neural crest, a view that continues to garner some support (Aumuller et al. 1999). However, the preponderance of current evidence favors an endodermal origin for neuroendocrine cells (like other prostatic epithelial cells), by analogy with a similar population of cells in the gut and pancreas (Andrew et al. 1983). Whereas neuroendocrine cells represent a relatively minor population in the normal prostate, the accumulation of cells with neuroendocrine features, referred to as neuroendocrine differentiation, is a hallmark of more aggressive forms of prostate cancer (di Sant'Agnese 1992; Allen et al. 1995; Weinstein et al. 1996; McWilliam et al. 1997; Abrahamsson et al. 1998; Cussenot et al. 1998). In most cases, cells with neuroendocrine features are dispersed within neoplastic foci, with increased neuroendocrine differentiation generally correlated with disease progression, but not necessarily with prognosis. In some cases, however, the neoplastic foci themselves are neuroendocrine, producing highly aggressive tumors that are termed small cell carcinoma.
In their now classic work, Isaacs and Coffey invoked the concept of a prostatic stem cell based on the regenerative capacity of the rat ventral prostate following castration-induced atrophy (Isaacs 1985; Kyprianou and Isaacs 1988; Isaacs and Coffey 1989). In subsequent studies, analysis of cytokeratin expression patterns has identified transient populations of prostatic epithelial cells having both basal and luminal characteristics (Verhagen et al. 1992; Bonkhoff et al. 1994). Based on these and other observations, as well as the properties of stem cells in other tissues, several groups have proposed the existence of a stem cell compartment within the prostatic epithelium (Bonkhoff and Remberger 1996; De Marzo et al. 1998b). This stem cell compartment is hypothesized to correspond to a subpopulation of androgen-independent basal cells. These stem cells would give rise to a transiently proliferating compartment, which are pluripotential androgen-responsive cells that in turn generate basal cells, differentiated luminal cells, and possibly the neuroendocrine cells. In support of this model, basal cells isolated by differential cell sorting can produce prostatic secretory proteins when cocultured with stromal cells (Liu et al. 1997); however, there is no direct evidence that the resulting epithelial cells are bona fide luminal cells or that they originated from the input basal cells. Thus, a direct demonstration of the existence of stem cells within the basal cell layer as well as their multilineage potential is currently lacking.

Elucidation of the lineage relationships within the prostatic epithelium is relevant for understanding the origins of prostate carcinoma. Although prostate cancer cells often express basal cell markers, loss of the basal cell layer is paradoxically a hallmark of neoplastic foci (Fig. 1F; Totten et al. 1953; Bostwick and Brawer 1987; Bostwick 1996). Moreover, since PSA is secreted exclusively by luminal cells, carcinoma cells have at least a partial luminal phenotype. One possible explanation for these observations is that transformed cells arise from the transiently proliferating progenitor compartment (De Marzo et al. 1998a,b), and thus may express characteristics of both the luminal and basal phenotype. Alternatively, neoplastic transformation might involve reversion of luminal cells to a less differentiated state that is reminiscent of the basal cell phenotype. Recently, prostate stem cell antigen (PSCA) has been identified as a cell surface marker that is expressed in normal basal cells and is up-regulated in prostate carcinoma (Reiter et al. 1998; Gu et al. 2000). Although it is not specific for prostate, PSCA may represent a marker to help resolve the lineage relationships among prostatic epithelial cells and their relationship to carcinoma.

\section{A pathway for prostate cancer initiation and progression: an overview}

In its initial stages, when confined to the prostatic capsule, prostate carcinoma is essentially curable by surgical intervention and/or radiation therapy. In fact, most cases of prostate carcinoma are relatively indolent, such that the majority of men diagnosed with prostate cancer 
will instead die of other causes. However, if not detected early, or in more aggressive forms of the disease, prostate carcinoma can advance to stages characterized by local invasion of the seminal vesicles, followed by metastasis primarily to the bone, usually resulting in lethality. This transition to metastatic disease is generally followed by a shift from androgen dependence to androgen independence, which is often provoked by androgen-ablation therapy.

Much research has focused on aspects of the clinical progression pathway that are pertinent issues for patient outcome. These aspects include: (1) identification of prognostic markers that distinguish the rare, aggressive forms of prostate cancer from the majority of indolent cancers; (2) understanding the mechanisms that lead to androgen independence; and (3) understanding how and why prostate cancer metastasizes preferentially to the bone. These issues have been extensively reviewed elsewhere (e.g., Harding and Theodorescu 1999; Lange and Vessella 1999; Pilat et al. 1999) and will not be discussed further here.

In contrast, less attention has been focused on the mechanisms underlying prostate cancer initiation, and on defining the parameters of a cancer progression pathway in molecular terms. One particularly fruitful area of investigation has been the analysis of chromosomal alterations that are commonly observed in prostate cancer. Therefore, as a starting point for discussion of a progression pathway, we will consider the characteristic patterns of chromosome abnormalities in prostate carcinoma as indicative of stages of prostate cancer progression (Fig. 4). Presumably, patterns of consistent allelic loss reflect the reduction or loss-of-function of putative tumor suppressor genes in prostate cancer. In particular, losses of heterozygosity at chromosomes $8 \mathrm{p}, 10 \mathrm{q}, 13 \mathrm{q}$, and $17 \mathrm{p}$ are frequent events, and losses of $6 \mathrm{q}, 7 \mathrm{q}, 16 \mathrm{q}$, and $18 \mathrm{q}$ have also been reported, although they are not as well characterized (Latil et al. 1994; Zenklusen et al.
1994; Takahashi et al. 1995; Cooney et al. 1996a; Cunningham et al. 1996; Elo et al. 1997; Latil et al. 1997; Saric et al. 1999). In addition, although chromosome gains appear to be less frequent than chromosome losses, gains at $8 \mathrm{q}$ and 7 are fairly common (Alcaraz et al. 1994; Bandyk et al. 1994; Van Den Berg et al. 1995).

Despite the significance of allelic loss for prostate carcinogenesis, no single candidate tumor suppressor gene has been definitively assigned a role in cancer progression. Several reasonable candidate genes (e.g., $R B, p 53$, $P T E N, N K X 3.1)$ have been implicated, based on their localization to regions of allelic loss and their functional properties (Table 1; discussed below), but none of these has been shown to be mutated in a large percentage of prostate cancer specimens. Unfortunately, in most cases there are conflicting reports in the literature regarding the frequency and nature of mutations of specific candidate genes.

There are accordingly several general possibilities to consider in the case of each candidate tumor suppressor gene. The first and most obvious possibility is that the actual tumor suppressor genes in the regions of allelic loss have yet to be identified. A second possibility is that the ability to detect mutations in candidate genes may be masked by the inability to obtain relatively pure tissue samples for analysis, because of tumor heterogeneity and multifocality. This technical explanation is quite conceivable because most analyses are still performed with relatively large tissue samples that are unlikely to be homogeneous. However, new developments in PCR technology (e.g., real-time PCR) may help overcome these difficulties by allowing analysis of small numbers of cells. A third possibility is that candidate genes may be inactivated by a mechanism other than a coding region mutation, such as promoter methylation or mutations within regulatory sequences that may affect transcription, translation, or mRNA stability. In addition, inactivation could occur through alterations of upstream
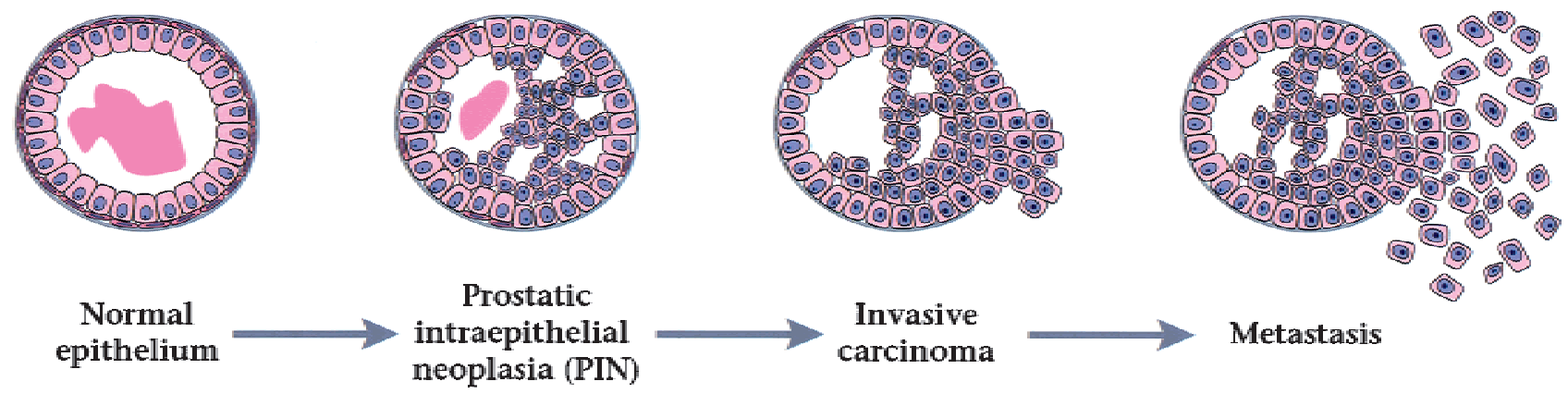

Invasive
carcinoma

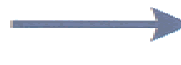

Metastasis

Loss of basal cells

Loss of basal lamina

Andragen-independence

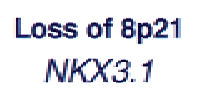

$\begin{array}{cc}\text { Loss of } 10 \mathrm{q} & \text { Loss of } \mathbf{1 3 q} \\ \text { PTEN } & R b\end{array}$

\section{Loss of $17 p$ p53}

Figure 4. Pathway for human prostate cancer progression. Stages of progression are correlated with loss of specific chromosome regions and candidate tumor suppressor genes. 
or downstream components in a regulatory pathway; indeed, few studies have examined multiple components of a given pathway concurrently. A final possibility is that haploinsufficiency (loss of a single allele) may play an important role in prostate carcinogenesis, perhaps consistent with the slow rate of progression and indolent phenotype of most tumors.

\section{Mechanisms of prostate cancer initiation}

\section{PIN is a precursor of carcinoma}

Histopathological studies of prostate cancer tissue have led to the identification of a specific type of lesion that is believed to represent the primary precursor of human prostate cancer (Fig. 1D-F). Known as PIN (McNeal and Bostwick 1986), this lesion can be classified into four common architectural types: tufting, micropapillary, cribiform, and flat (Bostwick and Brawer 1987; Nagle et al. 1991; Bostwick et al. 1993; Bostwick 1996, 1999). PIN is recognized as a continuum between low-grade and high-grade forms, with high-grade PIN thought to represent the immediate precursor of early invasive carcinoma.

Several lines of evidence implicate high-grade PIN (HGPIN) as a preneoplastic lesion in humans. First, PIN lesions are primarily found in the peripheral zone, in proximity to invasive carcinoma (Bostwick and Brawer 1987). Second, the appearance of HGPIN lesions generally precedes the appearance of carcinoma by at least 10 years, consistent with the idea of cancer progression (Sakr et al. 1993). Third, allelic imbalance analysis has shown that PIN lesions are multifocal, as is the case for carcinoma; moreover, the chromosomal abnormalities found in PIN resemble those found in early invasive carcinoma, although they are less prevalent (Sakr et al. 1994; Qian et al. 1995; Vocke et al. 1996; Haggman et al. 1997b). Fourth, the architectural and cytological features of PIN closely resemble those of invasive carcinoma, including disruption of the basal layer (Fig. 1F; Bostwick et al. 1993). Finally, markers of differentiation that are commonly altered in early invasive carcinoma are also altered in PIN lesions (Nagle et al. 1991; Haggman et al. 1997a). These include reduced expression of the cell adhesion protein E-cadherin and of the cytoskeletal component vimentin. On the other hand, PIN differs from invasive carcinoma in having an intact basement membrane, and thus does not invade the stroma (Fig. 1C,E; Bostwick et al. 1993). A second distinction is that PIN lesions do not produce high levels of PSA; consequently, PIN can only be detected in biopsy samples, and not by serum testing (Haggman et al. 1997a). Interestingly, PIN lesions are histologically similar to premalignant lesions of the breast-sometimes referred to as mammary intraepithelial neoplasia (MIN)_-(Tavassoli 1998; Cardiff et al. 2000), although there are also important distinctions (for discussion, see Bostwick et al. 1993).

Importantly, PIN lesions can be distinguished architecturally and cytologically from various other histopathological abnormalities of the prostatic epithelium, including benign prostatic hyperplasia (BPH) and atypical adenomatous hyperplasia (AAH), which are not believed to be precursor states for prostate cancer (Fig. 1B; Bostwick and Chang 1999). In particular, BPH is primarily found in the transition zone, and its histological features typically include expansion of the basal layer and stromal hyperproliferation, neither of which is associated with carcinoma (McNeal 1978, 1988). In contrast, the lesion described as proliferative inflammatory atrophy (PIA) has been proposed to be a precursor to PIN, and thus may represent an early step in carcinogenesis (De Marzo et al. 1999).

\section{Loss of chromosome $8 p$ and NKX3.1}

One of the most common events in early prostate carcinogenesis is the loss of specific regions of chromosome $8 \mathrm{p}$, which occurs in as many as $80 \%$ of prostate tumors, as well as in colorectal and lung carcinomas (Chang et al. 1994; Fujiwara et al. 1994; Matsuyama et al. 1994; Imbert et al. 1996; Wistuba et al. 1999). These chromosomal abnormalities have been detected by fluorescence in situ hybridization (FISH) (Macoska et al. 1993, 1994; Qian et al. 1995), comparative genomic hybridization (CGH) (Cher et al. 1994; Joos et al. 1995; Visakorpi et al. 1995b; Cher et al. 1996), and allelic imbalance analysis (Bergerheim et al. 1991; Bova et al. 1993; MacGrogan et al. 1994; Trapman et al. 1994; Emmert-Buck et al. 1995; Kagan et al. 1995; Suzuki et al. 1995; Cunningham et al. 1996; Vocke et al. 1996; Haggman et al. 1997b). In prostate cancer, frequent losses occur at two, and possibly three (Macoska et al. 1995), regions of $8 \mathrm{p}$, corresponding to $8 \mathrm{p} 12-21$ and $8 \mathrm{p} 22$. Many studies concur that loss of 8 p12-21 is an early event in prostate carcinogenesis, occurring in both PIN lesions and early invasive carcinomas, whereas loss of $8 \mathrm{p} 22$ is a later event because it is common in more advanced carcinomas.

Several lines of evidence support the idea that the NKX3.1 homeobox gene is a candidate for the $8 \mathrm{p} 1-21$ locus. First, NKX3.1 maps within the critical region of 8p12-21 lost in human prostate cancers /Voeller et al. 1997). Second, targeted gene disruption of Nkx3.1 in the mouse results in defects in prostate ductal morphogenesis and secretory function, consistent with a role for NKX3.1 in normal prostate differentiation (Bhatia-Gaur et al. 1999). Finally, Nkx3.1 mutant mice develop PINlike lesions that closely resemble human PIN (BhatiaGaur et al. 1999; M. Kim, M.M. Shen, and C. AbateShen, in prep.), suggesting that Nkx3.1 loss in mice models the predicted consequences of $8 \mathrm{p} 12-21$ loss in humans. On the other hand, mutations of the NKX3.1 coding sequence have not been detected in prostate carcinomas using SSCP analysis (Voeller et al. 1997), nor is NKX3.1 mRNA lost in prostate tumors (Xu et al. 2000). However, loss of a single $N k x 3.1$ allele in mice is sufficient for development of PIN lesions, raising the possibility that haploinsufficiency at 8p12-21 could account for the lack of NKX3.1 mutations in human cancer. In summary, although the evidence is far from unequivo- 
cal, NKX3.1 is likely to represent a regulatory gene whose loss is involved in prostate cancer initiation.

Since expression of NKX3.1 is restricted to the prostate in adult tissues (He et al. 1997; Bhatia-Gaur et al. 1999|, its loss or inactivation is unlikely to be relevant for lung or colorectal carcinomas, which also have deletions of $8 \mathrm{p}$ (Chang et al. 1994; Wistuba et al. 1999). Thus, 8p22 may harbor one or more tumor suppressor genes with broad-spectrum activities, in contrast to NKX3.1, which appears to be prostate-specific. A detailed map of 8p22 has been obtained (Bova et al. 1996), but candidate tumor suppressor genes in this region have not yet been identified.

\section{Mechanisms of prostate cancer progression}

\section{Loss of chromosome $10 q$ and PTEN}

Several parallels can be drawn between losses of chromosomal regions $10 \mathrm{q}$ and $8 \mathrm{p}$ in prostate cancer. First, loss of $10 \mathrm{q}$ is a frequent event $(-50 \%-80 \%)$ that has been detected by several independent strategies, including FISH, CGH, allelic imbalance, and cytogenetics (Carter et al. 1990b; Bergerheim et al. 1991; Macoska et al. 1993; Sakr et al. 1994; Gray et al. 1995; Cher et al. 1996; Ittmann 1996; Trybus et al. 1996; Saric et al. 1999), and also occurs frequently in other carcinomas (e.g., Kim et al. 1998). Second, at least two independent loci are involved that map to 10q23.1 and 10q24-q25. Finally, while several attractive candidates are found at these loci, their involvement in prostate carcinogenesis has not been established unequivocally. Importantly, loss of $10 \mathrm{q}$ is thought to be a later event in cancer progression than loss of $8 \mathrm{p}$, because it occurs more frequently in carcinoma and less frequently in PIN lesions.

Among potential candidate genes, PTEN/MMAC1 maps to $10 \mathrm{q} 23$, in a region that is lost in prostate carcinomas as well as several other carcinomas, including glioblastoma, breast, and endometrial cancers (for review, see Di Cristofano and Pandolfi 2000). PTEN mutations are frequently detected in patients with three autosomal dominant disorders-Cowden's disease, Lhermitte-Duclos disease, and Bannanyan-Zonana syndrome (Liaw et al. 1997)—whose syndromes share similar pathological features including the formation of benign tumors and an increased susceptibility to malignant cancer. PTEN encodes a lipid phosphatase whose main substrate is PIP-3; loss of PTEN function therefore results in activation of $\mathrm{PKB} / \mathrm{AKT}$ kinase activity, which in turn leads to decreased sensitivity to cell death. However, PTEN loss has also been associated with aberrant cellular proliferation (Sun et al. 1999), which suggests that its actual function may be dependent upon cellular context. Pten is widely expressed during mouse embryonic development and adulthood (Luukko et al. 1999), and targeted gene disruption results in homozygous embryonic lethality (Di Cristofano et al. 1998; Suzuki et al. 1998a; Podsypanina et al. 1999). Notably, Pten heterozygous mice develop severe dysplasia and carcinoma of several distinct cell types, including colon and skin.
Several lines of evidence implicate loss of PTEN as a key event in human prostate carcinogenesis. In the original characterization of the gene, PTEN was found to be mutated in all four prostate cell lines examined (Li et al. 1997; Steck et al. 1997). It was subsequently shown that PTEN is frequently lost in prostate cell lines and xenografts (Vlietstra et al. 1998), that it undergoes homozygous deletions in $\sim 10 \%$ of primary prostate tumors (Wang et al. 1998), and that alterations are more frequent in metastatic prostate cancer (Suzuki et al. 1998b). On the other hand, several studies have reported that mutations of PTEN are relatively rare in prostate carcinoma (Dong et al. 1998; Facher and Law 1998; Feilotter et al. 1998; Pesche et al. 1998). However, a functional role for $P T E N$ in prostate carcinogenesis has been supported by immunohistochemical data showing reduced expression of PTEN protein in primary tumors and xenografts (Whang et al. 1998; McMenamin et al. 1999), as well as increased AKT activity in xenograft models (Wu et al. 1998). Moreover, Pten heterozygous mutant mice develop prostatic epithelial hyperplasia and dysplasia (Di Cristofano et al. 1998; Podsypanina et al. 1999|, consistent with the growth suppressive activities of PTEN in prostate carcinoma cell lines (Davies et al. 1999; Sun et al. 1999). Therefore, despite the lack of reported mutations of PTEN in primary tumors, the evidence in favor of a central role for PTEN in prostate carcinogenesis is compelling.

Besides PTEN, a second candidate gene mapping to 10q25 is MXI1, which encodes a Myc-binding protein (Eagle et al. 1995). MXI1 protein is of particular interest given its intimate association with Myc protein, which has also been suggested to play a role in prostate cancer since it maps to a frequently amplified region of chromosome 8q (Van Den Berg et al. 1995; Bubendorf et al. 1999|. However, although Mxi1 mutant mice have been reported to display prostatic epithelial hyperplasia and dysplasia (Schreiber-Agus et al. 1998), this phenotype is relatively mild. In addition, despite initial reports suggesting that MXI1 is mutated with high frequency (Eagle et al. 1995; Prochownik et al. 1998), subsequent studies have failed to detect mutations in primary tumors (Kawamata et al. 1996; Kuczyk et al. 1998).

\section{Loss of chromosome $13 q$ and $\mathrm{Rb}$}

Loss of chromosome $13 \mathrm{q}$, including a region containing the Retinoblastoma $(R b)$ gene, occurs in at least $50 \%$ of prostate tumors (Cooney et al. 1996b; Melamed et al. 1997; Li et al. 1998). Indeed, early studies showed that reintroduction of $R b$ into prostate carcinoma cell lines lacking $R b$ inhibited tumorigenicity (Bookstein et al. $1990 b)$. In subsequent work, mutations of the $R b$ gene and loss of $\mathrm{Rb}$ protein expression have been reported in clinically localized as well as more advanced prostate carcinomas (Bookstein et al. 1990a; Phillips et al. 1994; Ittmann and Wieczorek 1996). Notably, $R b$ has been implicated in regulating apoptosis of prostate cells, particularly in response to androgens (Zhao et al. 1997; Bowen et al. 1998; Yeh et al. 1998). Furthermore, embryonic 
prostatic rescue and tissue recombination approaches have shown that homozygous loss of $R b$ results in dysplasia and invasive carcinoma, which can be exacerbated by hormonal stimulation (Wang et al. 2000). Several other studies, however, have failed to demonstrate mutations of $R b$ (Sarkar et al. 1992; Cooney et al. 1996b; Li et al. 1998), leading to the suggestion that loss of an alternative gene at $13 \mathrm{q}$ may be more significant for prostate carcinogenesis (e.g., Wieland et al. 1999). In a recurring theme, therefore, several lines of evidence have implicated $R b$ in prostate carcinogenesis, but definitive evidence is currently lacking.

\section{Altered cell-cycle regulatory genes}

In normal prostate epithelium, the relatively low rate of cell proliferation is balanced by a low rate of apoptosis (Berges et al. 1995). In contrast, PIN and early invasive carcinomas are characterized by a seven- to 10 -fold increase in the proliferation rate, whereas advanced and/or metastatic prostate cancers also display an approximately $60 \%$ decrease in the rate of apoptosis. Altered cell-cycle control is therefore likely to play a role in progression of clinically localized disease, whereas deregulated apoptosis may be more important for advanced carcinoma.

Among cell cycle regulatory genes, loss of function of the CDK4 inhibitor $p 27^{k i p 1}$ is particularly prevalent in prostate tumors, and may provide a prognostic marker of patient outcome (for review, see Macri and Loda 1999; Tsihlias et al. 1999). Notably, $p 27^{k i p 1}$ maps to $12 \mathrm{p} 12$ 13.1 (Pietenpol et al. 1995; Ponce-Castaneda et al. 1995), a region of frequent deletion in advanced prostate cancer (Kibel et al. 1998). Although loss of $p 27^{k i p 1}$ activity occurs frequently in many carcinomas, including breast and colon cancers, $p 27^{k i p 1}$ is rarely mutated. Instead, $p 27^{k i p 1}$ inactivation occurs through loss of expression or altered subcellular localization as a consequence of aberrant phosphorylation and/or ubiquitinylation (Esposito et al. 1997; Loda et al. 1997; Tan et al. 1997; Singh et al. 1998). In the prostate, several studies have demonstrated that loss of p27 protein expression correlates with tumor grade (Guo et al. 1997; Cote et al. 1998; De Marzo et al. 1998a; Tsihlias et al. 1998; Yang et al. 1998), and does not occur in BPH (Cordon-Cardo et al. 1998). Moreover, a functional role for $p 27^{k i p 1}$ in prostate carcinogenesis has been suggested by targeted gene disruption, which results in hyperplasia of multiple tissues including the prostate (Fero et al. 1996; Kiyokawa et al. 1996; Nakayama et al. 1996), and by the synergism between loss of $p 27^{k i p 1}$ with loss of $R b$ in tumorigenesis (Park et al. 1999). Haploinsufficiency of $p 27^{k i p 1}$ has also been shown to play a key role in tumor formation in several tissues in a mouse model (Fero et al. 1998), although the prostate was not examined in this study.

Another cell cycle regulator of particular interest is $p 16$, because its alteration is inversely correlated with that of $R b$ in other carcinomas (Otterson et al. 1994; Lukas et al. 1995; Ueki et al. 1996), and its loss is significant for bypassing senescence in many cell types, in- cluding prostate epithelial cells (Jarrard et al. 1999). However, with few exceptions (Chi et al. 1997), most studies have reported that $p 16$ is rarely mutated in primary prostate carcinomas, but is instead mutated in advanced metastatic disease (Chen et al. 1996; Tamimi et al. 1996; Gaddipati et al. 1997; Mangold et al. 1997; Park et al. 1997; Gu et al. 1998), although none of these studies examined the status of $R b$ in parallel. It has been suggested that in primary tumors, inactivation of $p 16$ may occur by deletion of one allele, combined with promoter methylation of the remaining allele (Jarrard et al. 1997). Surprisingly, up-regulation (rather than loss) of p16 protein has been reported to be a prognostic marker of disease recurrence in prostate cancer (Lee et al. 1999; Halvorsen et al. 2000). Although it is difficult to provide a mechanistic explanation for this finding, similar observations have been observed in other carcinomas (e.g., Dong et al. 1997).

In contrast to $p 27$ and $p 16$, the potential roles of other cell cycle regulatory genes in prostate cancer have not been thoroughly examined. For instance, overexpression of cyclin D1 is rare in primary prostate tumors (Gumbiner et al. 1999|, but is found in metastases as well as in prostate cell lines (Han et al. 1998; Drobnjak et al. 2000). In addition, although mutations of $p 21$ have not been reported in other human cancers, a somatic mutation of p21 was identified in human prostate cancer (Gao et al. 1995 ), and it has been proposed that p 21 protein expression may predict tumor recurrence (Aaltomaa et al. 1999; Sarkar et al. 1999).

\section{Aging and telomerase}

Aging appears to be the most critical factor in progression from HGPIN to early invasive carcinoma, but is the least well understood. This strong correlation of aging and onset of prostate carcinoma may be caused by the low proliferation rate of the prostatic epithelium, and the subsequently longer duration required for transforming events to occur. It is likely that this role of aging is also related to the activity of telomerase in overcoming replicative senescence in prostate carcinoma cells. Notably, PIN lesions and prostatic carcinoma, but not $\mathrm{BPH}$, display reduced telomere length with a concomitant increase in telomerase activity (Sommerfeld et al. 1996; Zhang et al. 1998). The recent development of mouse models with telomerase dysfunction should facilitate such functional studies of telomerase activity in prostate carcinogenesis (Lee et al. 1998).

\section{Mechanisms of progression to advanced carcinoma and metastatic disease}

\section{Androgen receptor signaling and cancer progression}

The most common treatment for advanced prostate cancer is androgen-ablation therapy, which effectively results in tumor regression over the short-term caused by massive apoptosis of androgen-dependent carcinoma 
cells (Huggins and Hodges 1941). In most cases, however, such treatment ultimately results in the recurrence of highly aggressive and metastatic prostate cancer that is androgen independent. This transition to androgen independence is likely to occur through selection for growth of androgen-independent cells that may already coexist within an androgen-dependent population prior to androgen deprivation (Isaacs and Coffey 1981; Gingrich et al. 1997). Because of these clinical implications, much research has focused on understanding how prostate cancer cells are able to escape their initial androgen dependence, as well as on the status of the androgen receptor (AR) when this occurs (for review, see Bentel and Tilley 1996; Culig et al. 1998; Koivisto et al. 1998).

Initially, it was believed that androgen-independent tumor growth was caused by loss of expression of AR mRNA and protein, because AR is not expressed in highly aggressive and/or metastatic rodent and human cell lines (Tilley et al. 1990; Culig et al. 1998). Contrary to expectations, however, it was subsequently shown that AR protein is expressed fairly homogeneously in primary tumors, recurrent local tumors, and even in metastases (van der Kwast et al. 1991; Ruizeveld de Winter et al. 1994; Hobisch et al. 1995; Sweat et al. 1999). These observations imply that carcinoma cells bypass the requirement for androgens through a mechanism that does not involve down-regulation of AR expression.

There appear to be several possible mechanisms for acquiring androgen independence, including alterations of AR activity, function, and/or specificity. One possibility is that AR function becomes highly sensitized to low levels of residual androgens. Indeed, AR is frequently mutated within the hormone-binding domain in both cell lines and primary tumors, rendering AR permissive for binding other steroid hormones, and thereby overcoming a specific requirement for androgens (Trapman et al. 1990; Veldscholte et al. 1992; Gaddipati et al. 1994; Elo et al. 1995).

However, AR mutations are found not only in the hormone-binding domain, but also throughout its coding region in primary tumors as well as in hormone-refractory disease (Newmark et al. 1992; Taplin et al. 1995; Tilley et al. 1996; for review, see Bentel and Tilley 1996). Other mutations that affect AR activity include amplification of CAG repeats, the length of which is inversely correlated with androgen action (Hakimi et al. 1996), and amplification of the entire AR gene, which may be prevalent in recurrent disease (Visakorpi et al. 1995a; Koivisto et al. 1998). Finally, it has been suggested that in cases when androgens are limiting (as occurs following androgen-ablation therapy), hormone requirements may be bypassed through synergistic activities of AR with growth factors such as IGF, FGF, and/or EGF (e.g., Culig et al. 1994).

\section{Loss of $17 p$ and $\mathrm{p} 53$}

Loss of chromosome 17p occurs in advanced stages of prostate cancer and metastatic disease (Cher et al. 1994, 1996; Saric et al. 1999|, deleting a region that includes the p53 locus, but not BRCA1 (Brooks et al. 1996). It is now generally accepted that mutations of p53 occur infrequently in early invasive carcinoma (Henke et al. 1994; Voeller et al. 1994; Prendergast et al. 1996), although not all studies concur (Chi et al. 1994). In contrast, p53 is mutated in advanced stages of prostate cancer, as well as in recurrent and metastatic disease, as inferred by immunocytochemical localization of accumulated protein (presumed to be indicative of its mutation) or by direct mutational analysis (Bookstein et al. 1993; Effert et al. 1993; Navone et al. 1993; Aprikian et al. 1994; Eastham et al. 1995; Heidenberg et al. 1995), again with dissenting reports (Dinjens et al. 1994). Moreover, several studies indicate that $p 53$ overexpression is a predictive factor for poor prognosis and disease recurrence, particularly when detected in combination with Bcl2 (Thomas et al. 1993; Shurbaji et al. 1995; Bauer et al. 1996; Moul et al. 1996; Matsushima et al. 1997; Theodorescu et al. 1997; Brewster et al. 1999; Stackhouse et al. 1999).

Interestingly, the frequency of $p 53$ mutations seems to be lower in prostate cancer than in other cancers. A relatively minor role for $p 53$ in prostate carcinogenesis is consistent with the observation that Li-Fraumeni patients carrying germline $p 53$ mutations have a low incidence of prostate cancer (Kleihues et al. 1997), although it may be the case that they succumb to other carcinomas before they can develop prostate cancer. An alternative possibility is that the variability in reported p53 mutation rates reflects a differential tissue-specific role of other components in the p53 pathway, particularly $m d m 2$ and $p 21$ (Osman et al. 1999). A final possibility is that p53 mutations occur frequently in prostate cancer, but are difficult to detect, since they appear to be associated with more highly aggressive and/or recurrent forms of the disease, for which tissue acquisition is more difficult (Visakorpi et al. 1992; Yang et al. 1996).

\section{Altered apoptotic regulatory genes}

Overexpression of Bcl2 in prostate carcinoma cells is a hallmark of advanced, hormone-refractory disease, and may account for the resistance to apoptosis that is characteristic of late stages (Colombel et al. 1993; Apakama et al. 1996; Furuya et al. 1996; McDonnell et al. 1997). Although Bcl2 expression is restricted to basal cells in the normal prostate (Hockenbery et al. 1991), forced expression of Bcl2 in LnCAP prostate carcinoma cells protects against apoptosis induced by androgen depletion (Raffo et al. 1995). Moreover, as is the case for p53, Bcl2 expression may provide a prognostic marker that correlates with disease outcome (Bubendorf et al. 1996; Keshgegian et al. 1998; Mackey et al. 1998). Indeed, several preliminary studies have examined whether $\mathrm{Bcl} 2$ inactivation may prevent tumor recurrence (Dorai et al. 1997; Gleave et al. 1999; Miyake et al. 1999|. Overexpression of $B c 12$ has been shown to confer resistance to chemotherapy in prostate carcinoma cell lines (Tu et al. 1995), and current clinical efforts are aimed at modulating the expression of Bcl2 (DiPaola 1999). Nonetheless, the sig- 
nificance of $B c 12$ activity in prostate cancer remains unclear, and other components of the apoptotic pathway have not been extensively examined (Krajewska et al. 1996; Johnson et al. 1998). Notably, transgenic mice in which $\mathrm{Bcl} 2$ was overexpressed in the prostate had a relatively mild phenotype (Zhang et al. 1997), which perhaps reflects relatively low-level transgene expression, rather than lack of Bcl2 activity.

\section{Murine models for prostate cancer}

Historically, a major limitation in studying prostate cancer has been the lack of suitable animal models that faithfully recapitulate all stages of disease progression (for review, see Navone et al. 1999). As a notable exception, dogs have been widely studied because they develop spontaneous high-grade PIN and prostate carcinoma as a correlate of aging, and display progression to androgen independence and metastasis to bone (Waters et al. 1998). Moreover, most animal models of prostate cancer are not amenable to genetic analyses.

The validity of the mouse as a model for prostate cancer has met with considerable controversy because of the absence of spontaneous prostate cancer in mice and the cross-species differences in prostate anatomy and morphology. Despite these concerns, many laboratories have undertaken the generation and use of xenograft and hormone-induction models, and more recently transgenic and knockout approaches. In particular, the prostate phenotypes of several transgenic and knockout mouse models appear closely analogous to the human disease, although these fail to display preferential metastasis to bone.

\section{Xenograft, reconstitution, and hormonal carcinogenesis models}

Despite difficulties in propagating human prostate tumors in immunodeficient mouse hosts, several groups have successfully generated xenografts that provide models for clinically advanced prostate cancer, as well as sources of human prostate cancer cell lines (e.g., Ellis et al. 1996; Klein et al. 1997). These xenograft models have been particularly valuable for studying the mechanisms involved in the transition to androgen independence (Craft et al. 1999) and correspond to one of the few available approaches for studying bone metastasis in mice. In addition, the discovery by Dunning of the rare, spontaneous occurrence of prostate cancer in an inbred Copenhagen rat has provided the basis for a set of serially transplantable murine cell lines that represent the spectrum from androgen-dependent, nonmetastatic carcinoma to androgen-independent, highly metastatic disease (Isaacs et al. 1986). These Dunning lines have been widely used in tumorigenicity studies employing subcutaneous or orthotopic inoculations, particularly for gene transfer approaches to identify chromosomal regions that contribute to metastases (Ichikawa et al. 1994; Rinker-Schaeffer et al. 1994). Finally, in vivo model systems to study stro- mal-epithelial interactions have used mixing of LNCaP cells with bone stromal cells, followed by injection into immunodeficient mouse hosts (Thalmann et al. 1994; Wu et al. 1994).

A conceptually related xenograft methodology has been developed in the mouse reconstituted prostate (MRP) model, which represents a variation of the tissue recombination technique discussed above. In this approach, urogenital sinus epithelium or mesenchyme is infected with retroviruses encoding dominantly acting oncogenes such as Myc or Ras, followed by recombination with the counterpart mesenchyme or epithelium and grafting under the renal capsule (Thompson et al. 1989; Lu et al. 1992). This approach was initially used to demonstrate synergy of Myc- and Ras-induced transformation, and subsequently to demonstrate a role for p53 loss in clonal expansion during cancer progression, as traced by analysis of unique retroviral integration sites (Thompson et al. 1989; Lu et al. 1992). Until recently, however, a primary limitation for this approach has been the low infectivity $(\sim 1 \%)$ of primary prostatic epithelial cells (Thompson et al. 1989). This restriction can now be overcome using immortalized cell lines that are capable of reconstituting prostatic tissue in tissue recombination experiments, as well as improved retroviral vectors that allow for higher titer infectivity.

Finally, hormone-inducible models were originally developed to test the hypothesis that altered androgen to estrogen ratios contribute to the onset and progression of prostate cancer (Mawhinney and Neubauer 1979). Indeed, subcutaneous implantation of capsules containing large doses of testosterone and estrogen results in highly reproducible progression from prostatic epithelial hyperplasia to invasive carcinoma. Although this methodology was initially developed in Noble rats (Leav et al. 1989; Wang and Wong 1998), recent adaptations have allowed the investigation of hormonal carcinogenesis in mutant mouse models (Wang et al. 2000).

\section{Transgenic models}

The identification of promoter elements that direct specific transgene expression to the prostate has facilitated the development of several mouse models of prostate cancer. In particular, the widely used promoter elements from the rat probasin gene can direct transgene expression to the ventral and dorsolateral prostate and to a lesser extent to the anterior prostate (Greenberg et al. 1994; Yan et al. 1997). Notably, a line of transgenic mice, known as the TRAMP (transgenic adenocarcinoma mouse prostate) model, contains a minimal probasin promoter driving expression of SV40 large T and small $t$ tumor antigens. These transgenic mice display highgrade PIN and/or prostate cancer within 12 weeks of age (Fig. 5), and ultimately develop metastases by 30 weeks primarily to the lungs and lymph nodes, and less often to bone, kidneys, and adrenal gland (Greenberg et al. 1995; Gingrich et al. 1996, 1997). Androgen depletion by castration results in variably decreased tumor incidence, but ultimately results in appearance of androgen-inde- 

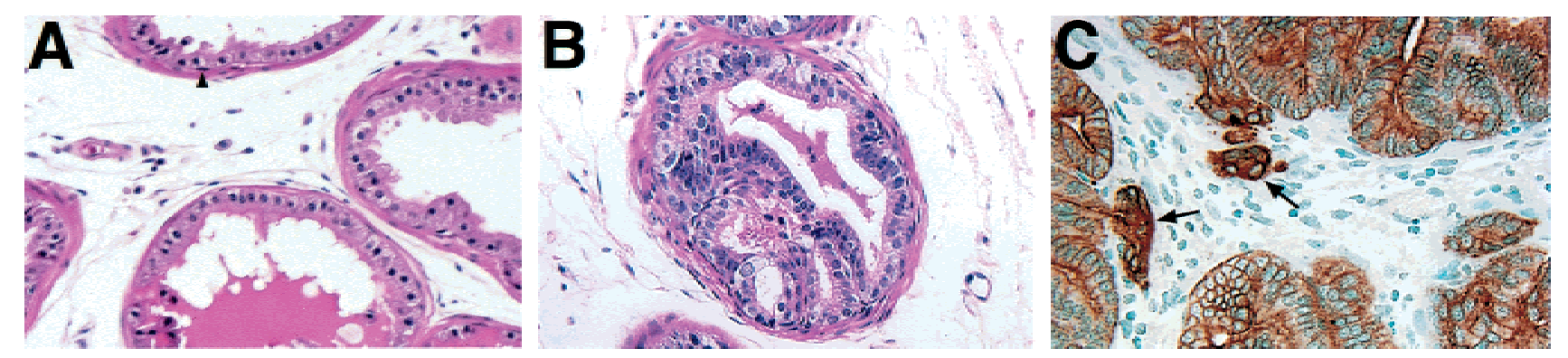

Figure 5. Histology of mouse prostate tissue. (A) Hematoxylin-eosin staining of wild-type dorsolateral prostate from a 12-week-old mouse; arrowhead indicates a basal cell. (B) Prostatic intraepithelial neoplasia (PIN) in the dorsolateral prostate of a TRAMP transgenic mouse. $(C)$ Immunohistochemical staining of prostate epithelial cells using a polyclonal recognizing high-molecular weight cytokeratins $(8,18$, and 19), showing stromal invasion by carcinoma cells (arrows) arising in a TRAMP mouse. Panels $B$ and $C$ were generously provided by Dr. Jeffrey Gingrich (University of Tennesee, Memphis) and Dr. Norman Greenberg (Baylor College of Medicine, Houston, TX); immunohistochemical staining in panel $C$ was performed by Dr. Barbara Foster (Baylor College of Medicine, Houston, TX).

pendent disease (Gingrich et al. 1997). Thus, the TRAMP mice recapitulate many salient aspects of human prostate cancer and have been used for a wide range of studies, such as analysis of aberrant growth factor signaling in prostate cancer progression (Foster et al. 1998; Kaplan et al. 1999). However, although the transition from lowgrade PIN to high-grade PIN to invasive carcinoma is fairly uniform in the TRAMP model, the pace of progression is extremely rapid.

Several related transgenic lines have been developed, in which a large $(12-\mathrm{kb})$ region of the rat probasin promoter (Yan et al. 1997) drives expression of SV40 large T antigen (Kasper et al. 1998). Perhaps because this transgene lacks small $t$ antigen, disease progression is less aggressive than in TRAMP mice; these mice are collectively named the lady model. Another important distinction between these models is the strain background in which they were derived, which may also contribute to differences in rate of tumor formation. The several lines arising from the large probasin-SV40 large $T$ transgene display varying but reproducible rates of tumor formation, ranging from 12 weeks to $>20$ weeks of age, presumably owing to copy number and/or integration site effects. Each of these lines consistently develops multifocal low-grade PIN that progresses to high-grade PIN and early invasive carcinoma but that generally fails to metastasize (Kasper et al. 1998). Androgen deprivation of these transgenic mice results in temporary regression, followed by the formation of poorly differentiated metastatic carcinomas (Kasper et al. 1998); these lines may therefore provide a model for the transition to androgen independence.

In addition to the probasin promoter, the promoter of the rat C3(1) prostate steroid-binding protein gene, which encodes a ventral prostate-specific protein, has been used to direct expression of SV4O large tumor antigen; similar lines have been generated using polyoma middle T (Maroulakou et al. 1994; Shibata et al. 1996). In the resulting transgenic mice, there appears to be a consistent and reproducible time course of progression from low-grade PIN to high-grade PIN to invasive carcinoma. However, the utility of these lines is limited by the onset of tumors in multiple tissue sites; moreover, the primary occurrence of androgen-independent tumors in the ventral prostatic lobe may limit their relevance for human cancer. Aside from the probasin and C3(1) promoters, few other prostate-specific promoters have been defined; notably, the human PSA promoter appears to be of limited usefulness in transgenic models (Schaffner et al. 1995).

A different category of transgenic models comprises those that develop neuroendocrine tumors of a highly aggressive nature (Skalnik et al. 1991; Perez-Stable et al. 1997; Garabedian et al. 1998; Lakshmanan et al. 1999), similar to human tumors with neuroendocrine differentiation. These models include Cryptdin-2 promoterSV40 T antigen mice, which rapidly develop PIN lesions followed by aggressive androgen-independent carcinomas that readily metastasize (Garabedian et al. 1998). Another transgenic model has used the fetal Gy-globin promoter linked to SV4O T antigen, which directs transgene expression to the prostate in a single line, presumably owing to chromosome integration context, leading to metastatic androgen-independent tumors with neuroendocrine differentiation (Perez-Stable et al. 1997). Finally, a gp91-phox transgene construct can fortuitously direct expression of SV40 early region to the prostate in several independent lines, again resulting in rapid onset of poorly differentiated neuroendocrine carcinomas (Skalnik et al. 1991). In each of these cases, there is no indication of an androgen-dependent stage prior to carcinoma formation; in addition, widespread transgene expression in other tissues limits their overall utility.

\section{Knockout models}

Relatively few mutant mouse models have been reported to display prostatic epithelial hyperplasia and dysplasia; among these are the Nkx3.1 and Pten mutant mice discussed above. Somewhat surprisingly, targeted disruption of numerous other tumor suppressor genes has not been reported to produce such prostatic epithelial defects. One likely explanation is that such mice may die of unrelated developmental defects or may succumb to 
tumors in other tissues before developing prostate cancer; an alternative possibility is that the prostate phenotype has not been examined.

Consequently, the creation of mouse reagents for prostate-specific gene targeting is a high priority, since it is likely to facilitate the development of additional mouse models for prostate cancer. Notably, probasin-Cre recombinase transgenic mice that may be suitable for Crelox $P$-mediated gene deletion in the prostate have recently been described (Maddison et al. 2000). Also of note, tissue rescue approaches that use renal capsule grafts of isolated urogenital anlage should allow investigation of the prostate phenotype of mutants that display mid-late gestation embryonic lethality (Wang et al. 2000). In combination, these approaches should circumvent many of the traditional barriers for reverse genetic analysis of prostate development and cancer.

\section{Future directions}

A primary goal for future research will be to establish a definitive molecular pathway of prostate cancer initiation and progression, accompanied by a precise understanding of the functional roles of candidate genes and regulatory pathways. Achieving this objective will require overcoming the significant obstacles imposed by limited availability of homogeneous genetic material from human prostate cancer specimens. The continued development of sensitive techniques for isolation and analysis of limited quantities of genomic DNA and mRNA should help overcome these limitations. In addition, the molecular identification and analysis of familial susceptibility genes for prostate cancer may provide critical breakthroughs in this endeavor.

Further advances in prostate cancer research will require a paradigmatic shift away from descriptive studies toward mechanistic and/or molecular analyses. Until recently, mouse models have been underutilized, perhaps owing to seemingly unwarranted concerns about the validity of the mouse as a model for human prostate cancer. Nonetheless, it is already evident that transgenic and mutant mice have provided excellent genetic models to dissect pathways of prostate carcinogenesis, and will obviously assume an increasingly significant role in the future. Along the way, this will require the characterization of additional prostate-specific promoters for the development of transgenic mice, as well as the development of mouse reagents for tissue-specific knockouts. In addition, the integration of prostate reconstitution strategies with improved retroviral gene transfer methodologies should provide an excellent approach for defining molecular components of a progression pathway.

In summary, although the molecular biology of prostate cancer has only just emerged from its infancy, the adolescent maturation of this field appears likely in the not-too-distant future. In particular, the advent of sophisticated mouse models will undoubtedly lead to crucial developments in our understanding of this muchfeared disease.

\section{Acknowledgments}

We are indebted to Robert Cardiff for providing images of human histopathology, and to Jeffery Gingrich and Norman Greenberg for providing images of TRAMP mouse histology. We also thank Robert Cardiff, Ron DePinho, Robert DiPaola, Norman Greenberg, Simon Hayward, and Arnold Rabson for critical reading of the manuscript. We apologize to those researchers whose work we have not been able to cite because of space constraints. Research in the laboratories of C.A.-S. and M.M.S. is supported by grants from the NIH (RO1CA76501, UO1CA84294), the Department of Defense (DAMD17-98-18532, PC991476), and the Gustavus and Louise Pfeiffer Research Foundation.

\section{References}

Aaltomaa, S., Lipponen, P., Eskelinen, M., Ala-Opas, M., and Kosma, V.M. 1999. Prognostic value and expression of p21(waf1/cip1) protein in prostate cancer. Prostate 39: 8-15.

Abrahamsson, P.A. 1999. Neuroendocrine differentiation in prostatic carcinoma. Prostate 39: 135-148.

Abrahamsson, P.A., Cockett, A.T., and di Sant'Agnese, P.A. 1998. Prognostic significance of neuroendocrine differentiation in clinically localized prostatic carcinoma. Prostate Suppl. 8: 37-42.

Alcaraz, A., Takahasi, S., Brown, J.A., Herath, J.F., Bergstralh, E.J., Larson-Keller, J.L., Lieber, M.M., and Jenkins, R.B. 1994. Aneuploidy and aneusomy of chromosome 7 detected by fluorescence in situ hybridization are markers of poor prognosis in prostate cancer. Cancer Res. 54: 3998-4002.

Allen, F.J., Van Velden, D.J., and Heyns, C.F. 1995. Are neuroendocrine cells of practical value as an independent prognostic parameter in prostate cancer? Brit. J. Urol. 75: 751-754.

Anderson, D.E. and Badzioch, M.D. 1992. Breast cancer risks in relatives of male breast cancer patients. J. Nat1. Cancer Inst. 84: 1114-1117.

Andrew, A., Kramer, B., and Rawdon, B.B. 1983. Gut and pancreatic amine precursor uptake and decarboxylation cells are not neural crest derivatives. Gastroenterology 84: 429-431.

Apakama, I., Robinson, M.C., Walter, N.M., Charlton, R.G., Royds, J.A., Fuller, C.E., Neal, D.E., and Hamdy, F.C. 1996. bcl-2 overexpression combined with p53 protein accumulation correlates with hormone-refractory prostate cancer. Brit. J. Cancer 74: 1258-1262.

Aprikian, A.G., Sarkis, A.S., Fair, W.R., Zhang, Z.F., Fuks, Z., and Cordon-Cardo, C. 1994. Immunohistochemical determination of p53 protein nuclear accumulation in prostatic adenocarcinoma. J. Urol. 151: 1276-1280.

Aumuller, G., Leonhardt, M., Janssen, M., Konrad, L., Bjartell, A., and Abrahamsson, P.A. 1999. Neurogenic origin of human prostate endocrine cells. Urology 53: 1041-1048.

Bandyk, M.G., Zhao, L., Troncoso, P., Pisters, L.L., Palmer, J.L., von Eschenbach, A.C., Leland, L.W.K., Leland, L.W.K., and Liang, J.C. 1994. Trisomy 7: A potential cytogenetic marker of human prostate cancer progression. Genes Chromosomes Cancer 9: 19-27.

Barkley, M.S. and Goldman, B.D. 1977. A quantitative study of serum testosterone, sex accessory organ growth, and the development of intermale aggression in the mouse. Horm. Behav. 8: 208-218.

Bauer, J.J., Sesterhenn, I.A., Mostofi, K.F., McLeod, D.G., Srivastava, S., and Moul, J.W. 1995. p53 nuclear protein expression is an independent prognostic marker in clinically localized prostate cancer patients undergoing radical prostatectomy. Clin. Cancer Res. 1: 1295-1300. 
1996. Elevated levels of apoptosis regulator proteins p53 and bcl-2 are independent prognostic biomarkers in surgically treated clinically localized prostate cancer. J. Urol. 156: 1511-1516.Bentel, J.M. and Tilley, W.D. 1996. Androgen receptors in prostate cancer. J. Endocrinol. 151: 1-11.

Bergerheim, U.S., Kunimi, K., Collins, V.P., and Ekman, P. 1991. Deletion mapping of chromosomes 8, 10, and 16 in human prostatic carcinoma. Genes Chromosomes Cancer 3: 215-220.

Berges, R.R., Vukanovic, J., Epstein, J.I., CarMichel, M., Cisek, L., Johnson, D.E., Veltri, R.W., Walsh, P.C., and Isaacs, J.T. 1995. Implication of cell kinetic changes during the progression of human prostatic cancer. Clin. Cancer Res. 1: 473480.

Bhatia-Gaur, R., Donjacour, A.A., Sciavolino, P.J., Kim, M., Desai, N., Young, P., Norton, C.R., Gridley, T., Cardiff, R.D., Cunha, G.R., et al. 1999. Roles for Nkx3.1 in prostate development and cancer. Genes \& Dev. 13: 966-977.

Bonkhoff, H. and Remberger, K. 1996. Differentiation pathways and histogenetic aspects of normal and abnormal prostatic growth: A stem cell model. Prostate 28: 98-106.

Bonkhoff, H., Stein, U., and Remberger, K. 1994. Multidirectional differentiation in the normal, hyperplastic, and neoplastic human prostate: Simultaneous demonstration of cellspecific epithelial markers. Hum. Pathol. 25: 42-46.

Bookstein, R., MacGrogan, D., Hilsenbeck, S.G., Sharkey, F., and Allred, D.C. 1993. p53 is mutated in a subset of advanced-stage prostate cancers. Cancer Res. 53: 3369-3373.

Bookstein, R., Rio, P., Madreperla, S.A., Hong, F., Allred, C., Grizzle, W.E., and Lee, W.H. 1990a. Promoter deletion and loss of retinoblastoma gene expression in human prostate carcinoma. Proc. Natl. Acad. Sci. 87: 7762-7766.

Bookstein, R., Shew, J.Y., Chen, P.L., Scully, P., and Lee, W.H. 1990b. Suppression of tumorigenicity of human prostate carcinoma cells by replacing a mutated RB gene. Science 247: 712-715.

Bostwick, D.G. 1996. Prospective origins of prostate carcinoma. Prostatic intraepithelial neoplasia and atypical adenomatous hyperplasia. Cancer 78: 330-336.

Bostwick, D.G. 1999. Prostatic intraepithelial neoplasia is a risk factor for cancer. Semin. Urol. Oncol. 17: 187-198.

Bostwick, D.G., Amin, M.B., Dundore, P., Marsh, W., and Schultz, D.S. 1993. Architectural patterns of high-grade prostatic intraepithelial neoplasia. Hum. Pathol. 24: 298-310.

Bostwick, D.G. and Brawer, M.K. 1987. Prostatic intra-epithelial neoplasia and early invasion in prostate cancer. Cancer 59: 788-794.

Bostwick, D.G. and Chang, L. 1999. Overdiagnosis of prostatic adenocarcinoma. Semin. Urol. Oncol. 17: 199-205.

Bostwick, D.G., Shan, A., Qian, J., Darson, M., Maihle, N.J., Jenkins, R.B., and Cheng, L. 1998. Independent origin of multiple foci of prostatic intraepithelial neoplasia: Comparison with matched foci of prostate carcinoma. Cancer 83: 19952002.

Bova, G.S., Carter, B.S., Bussemakers, M.J., Emi, M., Fujiwara, Y., Kyprianou, N., Jacobs, S.C., Robinson, J.C., Epstein, J.I., Walsh, P.C., et al. 1993. Homozygous deletion and frequent allelic loss of chromosome 8 p22 loci in human prostate cancer. Cancer Res. 53: 3869-3873.

Bova, G.S., MacGrogan, D., Levy, A., Pin, S.S., Bookstein, R., and Isaacs, W.B. 1996. Physical mapping of chromosome 8 p22 markers and their homozygous deletion in a metastatic prostate cancer. Genomics 35: 46-54.

Bowen, C., Spiegel, S., and Gelmann, E.P. 1998. Radiation-induced apoptosis mediated by retinoblastoma protein. Cancer Res. 58: 3275-3281.
Brawer, M.K., Peehl, D.M., Stamey, T.A., and Bostwick, D.G 1985. Keratin immunoreactivity in the benign and neoplastic human prostate. Cancer Res. 45: 3663-3667.

Brewster, S.F., Oxley, J.D., Trivella, M., Abbott, C.D., and Gillatt, D.A. 1999. Preoperative p53, bcl-2, CD44 and E-cadherin immunohistochemistry as predictors of biochemical relapse after radical prostatectomy. J. Urol. 161: 1238-1243.

Bright, R.K., Vocke, C.D., Emmert-Buck, M.R., Duray, P.H., Solomon, D., Fetsch, P., Rhim, J.S., Linehan, W.M., and Topalian, S.L. 1997. Generation and genetic characterization of immortal human prostate epithelial cell lines derived from primary cancer specimens. Cancer Res. 57: 995-1002.

Brooks, J.D., Bova, G.S., Ewing, C.M., Piantadosi, S., Carter, B.S., Robinson, J.C., Epstein, J.I., and Isaacs, W.B. 1996. An uncertain role for p53 gene alterations in human prostate cancers. Cancer Res. 56: 3814-3822.

Bubendorf, L., Kononen, J., Koivisto, P., Schraml, P., Moch, H., Gasser, T.C., Willi, N., Mihatsch, M.J., Sauter, G., and Kallioniemi, O.P. 1999. Survey of gene amplifications during prostate cancer progression by high-throughout fluorescence in situ hybridization on tissue microarrays. Cancer Res. 59: 803-806.

Bubendorf, L., Sauter, G., Moch, H., Jordan, P., Blochlinger, A., Gasser, T.C., and Mihatsch, M.J. 1996. Prognostic significance of Bcl-2 in clinically localized prostate cancer. Am. J. Pathol. 148: 1557-1565.

Bui, M. and Reiter, R.E. 1998. Stem cell genes in androgenindependent prostate cancer. Cancer Metastasis Rev. 17: 391-399.

Cannon, L., Bishop, D.T., Skolnick, M., Hunt, S., Lyon, J.L., and Smart, C.R. 1982. Genetic epidemiology of prostate cancer in the Utah mormon genealogy. Cancer Surveys 1: 47-69.

Cardiff, R.D., Anver, M.R., Gusterson, B.A., Hennighausen, L., Jensen, R.A., Merino, M.J., Rehm, S., Russo, J., Tavassoli, F.A., Wakefield, L.M., et al. 2000. The mammary pathology of genetically engineered mice: The consensus report and recommendations from the Annapolis meeting. Oncogene 19: 968-988.

Carter, B.S., Beaty, T.H., Steinberg, G.D., Childs, B., and Walsh, P.C. 1992. Mendelian inheritance of familial prostate cancer. Proc. Nat1. Acad. Sci. 89: 3367-3371.

Carter, B.S., Bova, G.S., Beaty, T.H., Steinberg, G.D., Childs, B., Isaacs, W.B., and Walsh, P.C. 1993. Hereditary prostate cancer: Epidemiologic and clinical features. J. Urol. 150: 797802.

Carter, B.S., Carter, H.B., and Isaacs, J.T. 1990a. Epidemiologic evidence regarding predisposing factors to prostate cancer. Prostate 16: 187-197.

Carter, B.S., Ewing, C.M., Ward, W.S., Treiger, B.F., Aalders, T.W., Schalken, J.A., Epstein, J.I., and Isaacs, W.B. 1990b. Allelic loss of chromosomes 16q and 10q in human prostate cancer. Proc. Natl. Acad. Sci. 87: 8751-8755.

Chan, J.M., Stampfer, M.J., Giovannucci, E., Gann, P.H., Ma, J., Wilkinson, P., Hennekens, C.H., and Pollak, M. 1998. Plasma insulin-like growth factor-I and prostate cancer risk: A prospective study. Science 279: 563-566.

Chang, M., Tsuchiya, K., Batchelor, R.H., Rabinovitch, P.S., Kulander, B.G., Haggitt, R.C., and Burmer, G.C. 1994. Deletion mapping of chromosome $8 \mathrm{p}$ in colorectal carcinoma and dysplasia arising in ulcerative colitis, prostatic carcinoma, and malignant fibrous histiocytomas. Am. J. Pathol. 144: 1-6.

Chen, W., Weghorst, C.M., Sabourin, C.L., Wang, Y., Wang, D., Bostwick, D.G., and Stoner, G.D. 1996. Absence of p16/ MTS1 gene mutations in human prostate cancer. Carcinogenesis 17: 2603-2607.

Cher, M.L., Bova, G.S., Moore, D.H., Small, E.J., Carroll, P.R., 
Pin, S.S., Epstein, J.I., Isaacs, W.B., and Jensen, R.H. 1996 Genetic alterations in untreated metastases and androgenindependent prostate cancer detected by comparative genomic hybridization and allelotyping. Cancer Res. 56: 30913102.

Cher, M.L., MacGrogan, D., Bookstein, R., Brown, J.A., Jenkins, R.B., and Jensen, R.H. 1994. Comparative genomic hybridization, allelic imbalance, and fluorescence in situ hybridization on chromosome 8 in prostate cancer. Genes Chromosomes Cancer 11: 153-162.

Chi, S.G., deVere White, R.W., Meyers, F.J., Siders, D.B., Lee, F., and Gumerlock, P.H. 1994. p53 in prostate cancer: Frequent expressed transition mutations. I. Natl. Cancer Inst. 86: $926-933$.

Chi, S.G., deVere White, R.W., Muenzer, J.T., and Gumerlock, P.H. 1997. Frequent alteration of CDKN2 ( $\left.p 16^{(I N K 4 A)} / M T S 1\right)$ expression in human primary prostate carcinomas. Clin. Cancer Res. 3: 1889-1897.

Coffey, D.S. 1993. Prostate cancer. An overview of an increasing dilemma. Cancer 71: 880-886.

Colombel, M., Symmans, F., Gil, S., O'Toole, K.M., Chopin, D., Benson, M., Olsson, C.A., Korsmeyer, S., and Buttyan, R. 1993. Detection of the apoptosis-suppressing oncoprotein bc1-2 in hormone-refractory human prostate cancers. Am. J. Pathol. 143: 390-400.

Cooney, K.A., Wetzel, J.C., Consolino, C.M., and Wojno, K.J. 1996a. Identification and characterization of proximal 6q deletions in prostate cancer. Cancer Res. 56: 4150-4153.

Cooney, K.A., Wetzel, J.C., Merajver, S.D., Macoska, J.A., Singleton, T.P., and Wojno, K.J. 1996b. Distinct regions of allelic loss on 13q in prostate cancer. Cancer Res. 56: 1142 1145 .

Cordon-Cardo, C., Koff, A., Drobnjak, M., Capodieci, P., Osman, I., Millard, S.S., Gaudin, P.B., Fazzari, M., Zhang, Z.F., Massague, J., et al. 1998. Distinct altered patterns of $p 27^{K I P 1}$ gene expression in benign prostatic hyperplasia and prostatic carcinoma. J. Natl. Cancer Inst. 90: 1284-1291.

Cote, R.J., Shi, Y., Groshen, S., Feng, A.C., Cordon-Cardo, C., Skinner, D., and Lieskovosky, G. 1998. Association of $p 27^{\text {Kip } 1}$ levels with recurrence and survival in patients with stage C prostate carcinoma. J. Natl. Cancer Inst. 90: $916-$ 920.

Craft, N., Chhor, C., Tran, C., Belldegrun, A., DeKernion, J., Witte, O.N., Said, J., Reiter, R.E., and Sawyers, C.L. 1999. Evidence for clonal outgrowth of androgen-independent prostate cancer cells from androgen-dependent tumors through a two-step process. Cancer Res. 59: 5030-5036.

Cress, A.E., Rabinovitz, I., Zhu, W., and Nagle, R.B. 1995. The alpha 6 beta 1 and alpha 6 beta 4 integrins in human prostate cancer progression. Cancer Metastasis Rev. 14: 219-228.

Culig, Z., Hobisch, A., Cronauer, M.V., Radmayr, C., Trapman, J., Hittmair, A., Bartsch, G., and Klocker, H. 1994. Androgen receptor activation in prostatic tumor cell lines by insulinlike growth factor-I, keratinocyte growth factor, and epidermal growth factor. Cancer Res. 54: 5474-5478.

Culig, Z., Hobisch, A., Hittmair, A., Peterziel, H., Cato, A.C., Bartsch, G., and Klocker, H. 1998. Expression, structure, and function of androgen receptor in advanced prostatic carcinoma. Prostate 35: 63-70.

Cunha, G.R. 1996. Growth factors as mediators of androgen action during male urogenital development. Prostate Suppl. 6: $22-25$.

Cunha, G.R., Donjacour, A.A., Cooke, P.S., Mee, S., Bigsby, R.M., Higgins, S.J., and Sugimura, Y. 1987. The endocrinology and developmental biology of the prostate. Endocr. Rev. 8: $338-362$.
Cunha, G.R., Donjacour, A.A., Hayward, S.W., Thomson, A.A., Marker, P.C., Abate-Shen, C., Shen, M., and Dahiya, R. 2000. Cellular and molecular biology of prostatic development. In Prostate cancer (ed. P.W. Kantoff, P. Carroll, and A. D'Amico), pp. 000-000. Lippincott, Williams and Wilkins, Philadelphia, PA.

Cunningham, J.M., Shan, A., Wick, M.J., McDonnell, S.K., Schaid, D.J., Tester, D.J., Qian, J., Takahashi, S., Jenkins, R.B., Bostwick, D.G., et al. 1996. Allelic imbalance and microsatellite instability in prostatic adenocarcinoma. Cancer Res. 56: 4475-4482.

Cussenot, O., Villette, J.M., Cochand-Priollet, B., and Berthon, P. 1998. Evaluation and clinical value of neuroendocrine differentiation in human prostatic tumors. Prostate Suppl. 8: $43-51$.

Dai, W.S., Kuller, L.H., LaPorte, R.E., Gutai, J.P., Falvo-Gerard, L., and Caggiula, A. 1981. The epidemiology of plasma testosterone levels in middle-aged men. Am. I. Epidemiol. 114: 804-816.

Davies, M.A., Koul, D., Dhesi, H., Berman, R., McDonnell, T.J., McConkey, D., Yung, W.K., and Steck, P.A. 1999. Regulation of Akt/PKB activity, cellular growth, and apoptosis in prostate carcinoma cells by MMAC/PTEN. Cancer Res. 59: 2551-2556.

De Marzo, A.M., Marchi, V.L., Epstein, J.I., and Nelson, W.G. 1999. Proliferative inflammatory atrophy of the prostate: Implications for prostatic carcinogenesis. Am. I. Path. 155: $1985-1992$.

De Marzo, A.M., Meeker, A.K., Epstein, J.I., and Coffey, D.S. 1998a. Prostate stem cell compartments: Expression of the cell cycle inhibitor $p 27^{K i p 1}$ in normal, hyperplastic, and neoplastic cells. Am. J. Pathol. 153: 911-919.

De Marzo, A.M., Nelson, W.G., Meeker, A.K., and Coffey, D.S. 1998b. Stem cell features of benign and malignant prostate epithelial cells. J. Urol. 160: 2381-2392.

Dhom, G. 1983. Epidemiologic aspects of latent and clinically manifest carcinoma of the prostate. J. Cancer Res. Clin. Oncol. 106: 210-218.

Di Cristofano, A. and Pandolfi, P.P. 2000. The multiple roles of PTEN in tumor suppression. Cell 100: 387-390.

Di Cristofano, A., Pesce, B., Cordon-Cardo, C., and Pandolfi, P.P. 1998. Pten is essential for embryonic development and tumour suppression. Nat. Genet. 19: 348-355.

Dinjens, W.N., van der Weiden, M.M., Schroeder, F.H., Bosman, F.T., and Trapman, J. 1994. Frequency and characterization of p53 mutations in primary and metastatic human prostate cancer. Int. J. Cancer 56: 630-633.

DiPaola, R.S. 1999. Approaches to the treatment of patients with hormone-sensitive prostate cancer. Semin. Oncol. 26: $24-27$.

DiPaola, R.S. and Aisner, J. 1999. Overcoming bcl-2- and p53mediated resistance in prostate cancer. Semin. Oncol. 26: $112-116$.

di Sant'Agnese, P.A. 1992. Neuroendocrine differentiation in carcinoma of the prostate. Diagnostic, prognostic, and therapeutic implications. Cancer 70: 254-268.

di Sant'Agnese, P.A. 1998. Neuroendocrine cells of the prostate and neuroendocrine differentiation in prostatic carcinoma: A review of morphologic aspects. Urology 51: 121-124.

Djakiew, D. 2000. Dysregulated expression of growth factors and their receptors in the development of prostate cancer. Prostate 42: 150-160.

Dong, J.T., Lamb, P.W., Rinker-Schaeffer, C.W., Vukanovic, J., Ichikawa, T., Isaacs, J.T., and Barrett, J.C. 1995. KAI1, a metastasis suppressor gene for prostate cancer on human chromosome 11p11.2. Science 268: 884-886. 
Dong, J.T., Sipe, T.W., Hyytinen, E.R., Li, C.L., Heise, C., McClintock, D.E., Grant, C.D., Chung, L.W., and Frierson, H.F., Jr. 1998. PTEN/MMAC1 is infrequently mutated in pT2 and pT3 carcinomas of the prostate. Oncogene 17: 1979-1982.

Dong, J.T., Suzuki, H., Pin, S.S., Bova, G.S., Schalken, J.A., Isaacs, W.B., Barrett, J.C., and Isaacs, J.T. 1996. Down-regulation of the KAI1 metastasis suppressor gene during the progression of human prostatic cancer infrequently involves gene mutation or allelic loss. Cancer Res. 56: 4387-4390.

Dong, Y., Walsh, M.D., McGuckin, M.A., Gabrielli, B.G., Cummings, M.C., Wright, R.G., Hurst, T., Khoo, S.K., and Parsons, P.G. 1997. Increased expression of cyclin-dependent kinase inhibitor 2 (CDKN2A) gene product P16INK4A in ovarian cancer is associated with progression and unfavourable prognosis. Intl. J. Cancer 74: 57-63.

Dorai, T., Olsson, C.A., Katz, A.E., and Buttyan, R. 1997. Development of a hammerhead ribozyme against bcl-2. I. Preliminary evaluation of a potential gene therapeutic agent for hormone-refractory human prostate cancer. Prostate 32: 246-258.

Drobnjak, M., Osman, I., Scher, H.I., Fazzari, M., and CordonCardo, C. 2000. Overexpression of Cyclin D1 is associated with metastatic prostate cancer to bone. Clin. Cancer Res. 6: 1891-1895.

Dunn, N.R., Winnier, G.E., Hargett, L.K., Schrick, J.J., Fogo, A.B., and Hogan, B.L. 1997. Haploinsufficient phenotypes in Bmp4 heterozygous null mice and modification by mutations in Gli3 and Alx4. Dev. Biol. 188: 235-247.

Eagle, L.R., Yin, X., Brothman, A.R., Williams, B.J., Atkin, N.B., and Prochownik, E.V. 1995. Mutation of the MXI1 gene in prostate cancer. Nat. Genet. 9: 249-255.

Eastham, J.A., Stapleton, A.M., Gousse, A.E., Timme, T.L., Yang, G., Slawin, K.M., Wheeler, T.M., Scardino, P.T., and Thompson, T.C. 1995. Association of p53 mutations with metastatic prostate cancer. Clin. Cancer Res. 1: 1111-1118.

Effert, P.J., McCoy, R.H., Walther, P.J., and Liu, E.T. 1993. p53 gene alterations in human prostate carcinoma. I. Urol. 150: $257-261$.

Ellis, W.J., Vessella, R.L., Buhler, K.R., Bladou, F., True, L.D., Bigler, S.A., Curtis, D., and Lange, P.H. 1996. Characterization of a novel androgen-sensitive, prostate-specific antigenproducing prostatic carcinoma xenograft: LuCaP 23. Clin. Cancer Res. 2: 1039-1048.

Elo, J.P., Harkonen, P., Kyllonen, A.P., Lukkarinen, O., Poutanen, M., Vihko, R., and Vihko, P. 1997. Loss of heterozygosity at 16q24.1-q24.2 is significantly associated with metastatic and aggressive behavior of prostate cancer. Cancer Res. 57: 3356-3359.

Elo, J.P., Kvist, L., Leinonen, K., Isomaa, V., Henttu, P., Lukkarinen, O., and Vihko, P. 1995. Mutated human androgen receptor gene detected in a prostatic cancer patient is also activated by estradiol. J. Clin. Endocrinol. Metab. 80: 34943500 .

Emmert-Buck, M.R., Bonner, R.F., Smith, P.D., Chuaqui, R.F., Zhuang, Z., Goldstein, S.R., Weiss, R.A., and Liotta, L.A. 1996. Laser capture microdissection. Science 274: 998-1001.

Emmert-Buck, M.R., Vocke, C.D., Pozzatti, R.O., Duray, P.H., Jennings, S.B., Florence, C.D., Zhuang, Z., Bostwick, D.G., Liotta, L.A., and Linehan, W.M. 1995. Allelic loss on chromosome 8p12-21 in microdissected prostatic intraepithelial neoplasia. Cancer Res. 55: 2959-2962.

Esposito, V., Baldi, A., De Luca, A., Groger, A.M., Loda, M., Giordano, G.G., Caputi, M., Baldi, F., Pagano, M., and Giordano, A. 1997. Prognostic role of the cyclin-dependent kinase inhibitor p27 in non-small cell lung cancer. Cancer Res. 57: 3381-3385.
Facher, E.A. and Law, J.C. 1998. PTEN and prostate cancer. J. Med. Genet. 35: 790.

Feilotter, H.E., Nagai, M.A., Boag, A.H., Eng, C., and Mulligan, L.M. 1998. Analysis of PTEN and the 10q23 region in primary prostate carcinomas. Oncogene 16: 1743-1748.

Fero, M.L., Randel, E., Gurley, K.E., Roberts, J.M., and Kemp, C.J. 1998. The murine gene $p 27^{\text {Kip } 1}$ is haplo-insufficient for tumour suppression. Nature 396: 177-180.

Fero, M.L., Rivkin, M., Tasch, M., Porter, P., Carow, C.E., Firpo, E., Polyak, K., Tsai, L.H., Broudy, V., Perlmutter, R.M., et al. 1996. A syndrome of multiorgan hyperplasia with features of gigantism, tumorigenesis, and female sterility in $p 27^{(\text {Kip } 1)}$. deficient mice. Cell 85: 733-744.

Foster, B.A., Kaplan, P.J., and Greenberg, N.M. 1998. Peptide growth factors and prostate cancer: New models, new opportunities. Cancer Metastasis Rev. 17: 317-324.

Fujiwara, Y., Ohata, H., Emi, M., Okui, K., Koyama, K., Tsuchiya, E., Nakajima, T., Monden, M., Mori, T., Kurimasa, A., et al. 1994. A 3-Mb physical map of the chromosome region 8p21.3-p22, including a 600-kb region commonly deleted in human hepatocellular carcinoma, colorectal cancer, and non-small cell lung cancer. Genes Chromosomes Cancer 10: 7-14.

Furuya, Y., Krajewski, S., Epstein, J.I., Reed, J.C., and Isaacs, J.T. 1996. Expression of bcl-2 and the progression of human and rodent prostatic cancers. Clin. Cancer Res. 2: 389-398.

Gaddipati, J.P., McLeod, D.G., Heidenberg, H.B., Sesterhenn, I.A., Finger, M.J., Moul, J.W., and Srivastava, S. 1994. Frequent detection of codon 877 mutation in the androgen receptor gene in advanced prostate cancers. Cancer Res. 54: 2861-2864.

Gaddipati, J.P., McLeod, D.G., Sesterhenn, I.A., Hussussian, C.J., Tong, Y.A., Seth, P., Dracopoli, N.C., Moul, J.W., and Srivastava, S. 1997. Mutations of the $p 16$ gene product are rare in prostate cancer. Prostate 30: 188-194.

Gao, X., Chen, Y.Q., Wu, N., Grignon, D.J., Sakr, W., Porter, A.T., and Honn, K.V. 1995. Somatic mutations of the WAF1/ CIP1 gene in primary prostate cancer. Oncogene 11: 13951398.

Garabedian, E.M., Humphrey, P.A., and Gordon, J.I. 1998. A transgenic mouse model of metastatic prostate cancer originating from neuroendocrine cells. Proc. Natl. Acad. Sci. 95: $15382-15387$.

Gingrich, J.R., Barrios, R.J., Kattan, M.W., Nahm, H.S., Finegold, M.J., and Greenberg, N.M. 1997. Androgen-independent prostate cancer progression in the TRAMP model. Cancer Res. 57: 4687-4691.

Gingrich, J.R., Barrios, R.J., Morton, R.A., Boyce, B.F., DeMayo, F.J., Finegold, M.J., Angelopoulou, R., Rosen, J.M., and Greenberg, N.M. 1996. Metastatic prostate cancer in a transgenic mouse. Cancer Res. 56: 4096-4102.

Gleason, D.F. 1992. Histologic grading of prostate cancer: A perspective. Hum. Pathol. 23: 273-279.

Gleave, M., Tolcher, A., Miyake, H., Nelson, C., Brown, B., Beraldi, E., and Goldie, J. 1999. Progression to androgen independence is delayed by adjuvant treatment with antisense Bcl-2 oligodeoxynucleotides after castration in the LNCaP prostate tumor model. Clin. Cancer Res. 5: 2891-2898.

Gray, I.C., Phillips, S.M., Lee, S.J., Neoptolemos, J.P., Weissenbach, J., and Spurr, N.K. 1995. Loss of the chromosomal region 10q23-25 in prostate cancer. Cancer Res. 55: 48004803.

Greenberg, N.M., DeMayo, F., Finegold, M.J., Medina, D., Tilley, W.D., Aspinall, J.O., Cunha, G.R., Donjacour, A.A., Matusik, R.J., and Rosen, J.M. 1995. Prostate cancer in a transgenic mouse. Proc. Nat1. Acad. Sci. 92: 3439-3443. 
Greenberg, N.M., DeMayo, F.J., Sheppard, P.C., Barrios, R., Lebovitz, R., Finegold, M., Angelopoulou, R,. Dodd, J.G., Duckworth, M.L., Rosen, J.M., et al. 1994. The rat probasin gene promoter directs hormonally and developmentally regulated expression of a heterologous gene specifically to the prostate in transgenic mice. Mol. Endocrinol. 8: 230239.

Gu, K., Mes-Masson, A.M., Gauthier, J., and Saad, F. 1998. Analysis of the p16 tumor suppressor gene in early-stage prostate cancer. Mol. Carcinog. 21: 164-170.

Gu, Z., Thomas, G., Yamashiro, J., Shintaku, I.P., Dorey, F., Raitano, A., Witte, O.N., Said, J.W., Loda, M., and Reiter, R.E. 2000. Prostate stem cell antigen (PSCA) expression increases with high gleason score, advanced stage and bone metastasis in prostate cancer. Oncogene 19: 1288-1296.

Gumbiner, L.M., Gumerlock, P.H., Mack, P.C., Chi, S.G., deVere White, R.W., Mohler, J.L., Pretlow, T.G., and Tricoli, J.V. 1999. Overexpression of cyclin D1 is rare in human prostate carcinoma. Prostate 38: 40-45.

Guo, Y., Sklar, G.N., Borkowski, A., and Kyprianou, N. 1997. Loss of the cyclin-dependent kinase inhibitor $\mathrm{p} 27^{(\mathrm{Kip} 1)}$ protein in human prostate cancer correlates with tumor grade. Clin. Cancer Res. 3: 2269-2274.

Haggman, M.J., Macoska, J.A., Wojno, K.J., and Oesterling, J.E. 1997a. The relationship between prostatic intraepithelial neoplasia and prostate cancer: Critical issues. J. Urol. 158: $12-22$.

Haggman, M.J., Wojno, K.J., Pearsall, C.P., and Macoska, J.A. $1997 \mathrm{~b}$. Allelic loss of $8 \mathrm{p}$ sequences in prostatic intraepithelial neoplasia and carcinoma. Urology 50: 643-647.

Hakimi, J.M., Rondinelli, R.H., Schoenberg, M.P., and Barrack, E.R. 1996. Androgen-receptor gene structure and function in prostate cancer. World J. Urol. 14: 329-337.

Halvorsen, O.J., Hostmark, J., Haukaas, S., Hoisaeter, P.A., and Akslen, L.A. 2000. Prognostic significance of p16 and CDK4 proteins in localized prostate carcinoma. Cancer 88: 416424.

Han, E.K., Lim, J.T., Arber, N., Rubin, M.A., Xing, W.Q., and Weinstein, I.B. 1998. Cyclin D1 expression in human prostate carcinoma cell lines and primary tumors. Prostate 35: 95-101.

Harding, M.A. and Theodorescu, D. 1999. Prognostic markers in localized prostate cancer: From microscopes to molecules. Cancer Metastasis Rev. 17: 429-437.

Hayashi, N., Sugimura, Y., Kawamura, J., Donjacour, A.A., and Cunha, G.R. 1991. Morphological and functional heterogeneity in the rat prostatic gland. Biol. Reprod. 45: 308-321.

Hayward, S.W., Rosen, M.A., and Cunha, G.R. 1997. Stromalepithelial interactions in the normal and neoplastic prostate. Brit. J. Urol. 79(Suppl 2): 18-26.

He, W.W., Sciavolino, P.J., Wing, J., Augustus, M., Hudson, P., Meissner, P.S., Curtis, R.T., Shell, B.K., Bostwick, D.G., Tindall, D.J., et al. 1997. A novel human prostate-specific, androgen-regulated homeobox gene (NKX3.1) that maps to 8 p21, a region frequently deleted in prostate cancer. Genomics 43: 69-77.

Heidenberg, H.B., Sesterhenn, I.A., Gaddipati, J.P., Weghorst, C.M., Buzard, G.S., Moul, J.W., and Srivastava, S. 1995. Alteration of the tumor suppressor gene $p 53$ in a high fraction of hormone refractory prostate cancer. J. Urol. 154: 414-421.

Henke, R.P., Kruger, E., Ayhan, N., Hubner, D., Hammerer, P., and Huland, H. 1994. Immunohistochemical detection of p53 protein in human prostatic cancer. J. Urol. 152: $1297-$ 1301.

Hobisch, A., Culig, Z., Radmayr, C., Bartsch, G., Klocker, H., and Hittmair, A. 1995. Distant metastases from prostatic carcinoma express androgen receptor protein. Cancer Res. 55: 3068-3072.

Hockenbery, D.M., Zutter, M., Hickey, W., Nahm, M., and Korsmeyer, S.J. 1991. BCL2 protein is topographically restricted in tissues characterized by apoptotic cell death. Proc. Natl. Acad. Sci. 88: 6961-6965.

Huggins, C. and Hodges, C.V. 1941. Studies in prostatic cancer. I. The effects of castration, of estrogen and of androgen injection of serum phosphatases in metastatic carcinoma of the prostate. Cancer Res. 1: 293-302.

Ichikawa, T., Nihei, N., Suziki, H., Oshimura, M., Emi, M., Nakamura, Y., Hayata, I., Isaacs, J.T., and Shimazaki, J. 1994. Suppression of metastases of rat prostatic cancer by introducing human chromosome 8. Cancer Res. 54: 2299-3202.

Imbert, A., Chaffanet, M., Essioux, L., Noguchi, T., Adelaide, J., Kerangueven, F., Le Paslier, D., Bonaiti-Pellie, C., Sobol, H., Birnbaum, D., et al. 1996. Integrated map of the chromosome 8p12-p21 region, a region involved in human cancers and Werner syndrome. Genomics 32: 29-38.

Isaacs, J.T. 1985. Control of cell proliferation and death in the normal and neoplastic prostate: A stem cell model. In Benign prostatic hyperplasia (ed. C.H. Rogers, D.S. Coffey, and G.R. Cunha), pp. 85-94. National Institutes of Health, Bethesda, $\mathrm{MD}$.

Isaacs, J.T. and Coffey, D.S. 1981. Adaptation versus selection as the mechanism responsible for the relapse of prostatic cancer to androgen ablation therapy as studied in the Dunning R-3327-H adenocarcinoma. Cancer Res. 41: 5070-5075.

1989. Etiology and disease process of benign prostatic hyperplasia. Prostate Suppl. 2: 33-50.

Isaacs, J.T., Isaacs, W.B., Feitz, W.F.J., and Scheres, J. 1986. Establishment and characterization of seven Dunning rat prostatic cancer cell lines and their use in developing methods for predicting metastatic abilities of prostate cancers. Prostate 9: 261-281.

Ittmann, M. 1996. Allelic loss on chromosome 10 in prostate adenocarcinoma. Cancer Res. 56: 2143-2147.

Ittmann, M.M. and Wieczorek, R. 1996. Alterations of the retinoblastoma gene in clinically localized, stage B prostate adenocarcinomas. Hum. Pathol. 27: 28-34.

Jarrard, D.F., Bova, G.S., Ewing, C.M., Pin, S.S., Nguyen, S.H., Baylin, S.B., Cairns, P., Sidransky, D., Herman, J.G., and Isaacs, W.B. 1997. Deletional, mutational, and methylation analyses of CDKN2 (p16/MTS1) in primary and metastatic prostate cancer. Genes Chromosomes Cancer 19: 90-96.

Jarrard, D.F., Sarkar, S., Shi, Y., Yeager, T.R., Magrane, G., Kinoshita, H., Nassif, N., Meisner, L., Newton, M.A., Waldman, F.M., et al. 1999. p16/pRb pathway alterations are required for bypassing senescence in human prostate epithelial cells. Cancer Res. 59: 2957-2964.

Jean-Faucher, C., Berger, M., de Turckheim, M., Veyssiere, G., and Jean, C. 1978. Developmental patterns of plasma and testicular testosterone in mice from birth to adulthood. Acta Endocrinol. (Copenh.) 89: 780-788.

Johnson, M.I., Robinson, M.C., Marsh, C., Robson, C.N., Neal, D.E., and Hamdy, F.C. 1998. Expression of Bcl-2, Bax, and p53 in high-grade prostatic intraepithelial neoplasia and localized prostate cancer: Relationship with apoptosis and proliferation. Prostate 37: 223-229.

Joos, S., Bergerheim, U.S., Pan, Y., Matsuyama, H., Bentz, M., du Manoir, S., and Lichter, P. 1995. Mapping of chromosomal gains and losses in prostate cancer by comparative genomic hybridization. Genes Chromosomes Cancer 14: 267-276.

Kagan, J., Stein, J., Babaian, R.J., Joe, Y.S., Pisters, L.L., Glassman, A.B., von Eschenbach, A.C., and Troncoso, P. 1995. Homozygous deletions at $8 \mathrm{p} 22$ and $8 \mathrm{p} 21$ in prostate cancer 
implicate these regions as the sites for candidate tumor suppressor genes. Oncogene 11: 2121-2126.

Kaplan, P.J., Mohan, S., Cohen, P., Foster, B.A., and Greenberg, N.M. 1999. The insulin-like growth factor axis and prostate cancer: Lessons from the transgenic adenocarcinoma of mouse prostate (TRAMP) model. Cancer Res. 59: 22032209.

Kasper, S., Sheppard, P.C., Yan, Y., Pettigrew, N., Borowsky, A.D., Prins, G.S., Dodd, J.G., Duckworth, M.L., and Matusik, R.J. 1998. Development, progression, and androgendependence of prostate tumors in probasin-large $T$ antigen transgenic mice: A model for prostate cancer. Lab. Invest. 78: 319-333; errata 78(6): i-xv.

Kawamata, N., Park, D., Wilczynski, S., Yokota, J., and Koeffler, H.P. 1996. Point mutations of the Mxil gene are rare in prostate cancers. Prostate 29: 191-193.

Keshgegian, A.A., Johnston, E., and Cnaan, A. 1998. Bcl-2 oncoprotein positivity and high MIB-1 (Ki-67) proliferative rate are independent predictive markers for recurrence in prostate carcinoma. Am. J. Clin. Pathol. 110: 443-449.

Kibel, A.S., Schutte, M., Kern, S.E., Isaacs, W.B., and Bova, G.S. 1998. Identification of $12 \mathrm{p}$ as a region of frequent deletion in advanced prostate cancer. Cancer Res. 58: 5652-5655.

Kim, S.K., Ro, J.Y., Kemp, B.L., Lee, J.S., Kwon, T.J., Hong, W.K., and Mao, L. 1998. Identification of two distinct tumor-suppressor loci on the long arm of chromosome 10 in small cell lung cancer. Oncogene 17: 1749-1753.

Kiyokawa, H., Kineman, R.D., Manova-Todorova, K.O., Soares, V.C., Hoffman, E.S., Ono, M., Khanam, D., Hayday, A.C., Frohman, L.A., and Koff, A. 1996. Enhanced growth of mice lacking the cyclin-dependent kinase inhibitor function of p27(Kip1). Cell 85: 721-732.

Kleihues, P., Schäuble, B., zur Hausen, A., Esteve, J., and Ohgaki, H. 1997. Tumors associated with p53 germline mutations: A synopsis of 91 families. Am. J. Path. 150: 1-13.

Klein, K.A., Reiter, R.E., Redula, J., Moradi, H., Zhu, X.L., Brothman, A.R., Witte, O.N., and Sawyers, C.L. 1997. Progression of metastatic human prostate cancer to androgen independence in immunodeficient SCID mice. Nature Medicine 3: 402-408.

Kleinerman, D.I., Troncoso, P., Lin, S.H., Pisters, L.L., Sherwood, E.R., Brooks, T., von Eschenbach, A.C., and Hsieh, J.T. 1995. Consistent expression of an epithelial cell adhesion molecule (C-CAM) during human prostate development and loss of expression in prostate cancer: Implication as a tumor suppressor. Cancer Res. 55: 1215-1220.

Koivisto, P., Kolmer, M., Visakorpi, T., and Kallioniemi, O.P. 1998. Androgen receptor gene and hormonal therapy failure of prostate cancer. Am. J. Pathol. 152: 1-9.

Krajewska, M., Krajewski, S., Epstein, J.I., Shabaik, A., Sauvageot, J., Song, K., Kitada, S., and Reed, J.C. 1996. Immunohistochemical analysis of bcl-2, bax, bcl-X, and mcl-1 expression in prostate cancers. Am. J. Pathol. 148: 1567-1576.

Kuczyk, M.A., Serth, J., Bokemeyer, C., Schwede, J., Herrmann, R., Machtens, S., Grunewald, V., Hofner, K., and Jonas, U. 1998. The MXI1 tumor suppressor gene is not mutated in primary prostate cancer. Oncol. Rep. 5: 213-216.

Kyprianou, N. and Isaacs, J.T. 1988. Activation of programmed cell death in the rat ventral prostate after castration. Endocrinology 122: 552-562.

Lakshmanan, G., Lieuw, K.H., Lim, K.C., Gu, Y., Grosveld, F., Engel, J.D., and Karis, A. 1999. Localization of distant urogenital system-, central nervous system-, and endocardiumspecific transcriptional regulatory elements in the GATA-3 locus. Mol. Cell Biol. 19: 1558-1568.

Lange, P.H. and Vessella, R.L. 1999. Mechanisms, hypotheses and questions regarding prostate cancer micrometastases to bone. Cancer Metastasis Rev. 17: 331-336.

Latil, A., Baron, J.C., Cussenot, O., Fournier, G., Soussi, T., Boccon-Gibod, L., Le Duc, A., Rouesse, J., and Lidereau, R. 1994. Genetic alterations in localized prostate cancer: Identification of a common region of deletion on chromosome arm 18q. Genes Chromosomes Cancer 11: 119-125.

Latil, A., Cussenot, O., Fournier, G., Driouch, K., and Lidereau, R. 1997. Loss of heterozygosity at chromosome 16q in prostate adenocarcinoma: Identification of three independent regions. Cancer Res. 57: 1058-1062.

Leav, I., Merk, F.B., Kwan, P.W.L., and Ho, S.M. 1989. Androgen-supported estrogen-enhanced epithelial proliferation in the prostates of intact Nobel rats. Prostate 15: 23-40.

Lee, C.T., Capodieci, P., Osman, I., Fazzari, M., Ferrara, J., Scher, H.I., and Cordon-Cardo, C. 1999. Overexpression of the cyclin-dependent kinase inhibitor p16 is associated with tumor recurrence in human prostate cancer. Clin. Cancer Res. 5: 977-983.

Lee, H.W., Blasco, M.A., Gottlieb, G.J., Horner, J.W., II, Greider, C.W., and DePinho, R.A. 1998. Essential role of mouse telomerase in highly proliferative organs. Nature 392: 569574.

Li, C., Larsson, C., Futreal, A., Lancaster, J., Phelan, C., Aspenblad, U., Sundelin, B., Liu, Y., Ekman, P., Auer, G., et al. 1998. Identification of two distinct deleted regions on chromosome 13 in prostate cancer. Oncogene 16: 481-487.

Li, J., Yen, C., Liaw, D., Podsypanina, K., Bose, S., Wang, S.I., Puc, J., Miliaresis, C., Rodgers, L, McCombie, R., et al. 1997. $P T E N$, a putative protein tyrosine phosphatase gene mutated in human brain, breast, and prostate cancer. Science 275: 1943-1947.

Liaw, D., Marsh, D.J., Li, J., Dahia, P.L., Wang, S.I., Zheng, Z., Bose, S., Call, K.M., Tsou, H.C., Peacocke, M., et al. 1997. Germline mutations of the PTEN gene in Cowden disease, an inherited breast and thyroid cancer syndrome. Nat. Genet. 16: 64-67.

Liu, A.Y., True, L.D., LaTray, L., Ellis, W.J., Vessella, R.L., Lange, P.H., Higano, C.S., Hood, L., and van den Engh, G. 1999. Analysis and sorting of prostate cancer cell types by flow cytometry. Prostate 40: 192-199.

Liu, A.Y., True, L.D., LaTray, L., Nelson, P.S., Ellis, W.J., Vessella, R.L., Lange, P.H., Hood, L., and van den Engh, G. 1997. Cell-cell interaction in prostate gene regulation and cytodifferentiation. Proc. Natl. Acad. Sci. 94: 10705-10710.

Loda, M., Cukor, B., Tam, S.W., Lavin, P., Fiorentino, M., Draetta, G.F., Jessup, J.M., and Pagano, M. 1997. Increased proteasome-dependent degradation of the cyclin-dependent kinase inhibitor p27 in aggressive colorectal carcinomas. Nat. Med. 3: 231-234.

Lu, X., Park, S.H., Thompson, T.C., and Lane, D.P. 1992. rasinduced hyperplasia occurs with mutation of $p 53$, but activated ras and myc together can induce carcinoma without p53. Cell 70: 153-161.

Lukas, J., Parry, D., Aagaard, L., Mann, D.J., Bartkova, J., Strauss, M., Peters, G., and Bartek, J. 1995. Retinoblastomaprotein-dependent cell-cycle inhibition by the tumour suppressor p16. Nature 375: 503-506.

Luukko, K., Ylikorkala, A., Tiainen, M., and Makela, T.P. 1999. Expression of LKB1 and PTEN tumor suppressor genes during mouse embryonic development. Mech. Dev. 83: 187190.

MacGrogan, D., Levy, A., Bostwick, D., Wagner, M., Wells, D., and Bookstein, R. 1994. Loss of chromosome arm 8p loci in prostate cancer: Mapping by quantitative allelic imbalance. Genes Chromosomes Cancer 10: 151-159. 
Macintosh, C.A., Stower, M., Reid, N., and Maitland, N.J. 1998. Precise microdissection of human prostate cancers reveals genotypic heterogeneity. Cancer Res. 58: 23-28.

Mackey, T.J., Borkowski, A., Amin, P., Jacobs, S.C., and Kyprianou, N. 1998. bcl-2/bax ratio as a predictive marker for therapeutic response to radiotherapy in patients with prostate cancer. Urology 52: 1085-1090.

Macoska, J.A., Micale, M.A., Sakr, W.A., Benson, P.D., and Wolman, S.R. 1993. Extensive genetic alterations in prostate cancer revealed by dual PCR and FISH analysis. Genes Chromosomes Cancer 8: 88-97.

Macoska, J.A., Trybus, T.M., Benson, P.D., Sakr, W.A., Grignon, D.J., Wojno, K.D., Pietruk, T., and Powell, I.J. 1995. Evidence for three tumor suppressor gene loci on chromosome $8 p$ in human prostate cancer. Cancer Res. 55: 5390-5395.

Macoska, J.A., Trybus, T.M., Sakr, W.A., Wolf, M.C., Benson, P.D., Powell, I.J., and Pontes, J.E. 1994. Fluorescence in situ hybridization analysis of $8 \mathrm{p}$ allelic loss and chromosome 8 instability in human prostate cancer. Cancer Res. 54: 3824 3830.

Macri, E. and Loda, M. 1999. Role of p27 in prostate carcinogenesis. Cancer Metastasis Rev. 17: 337-344.

Maddison, L.A., Nahm, H., DeMayo, F., and Greenberg, N.M. 2000. Prostate specific expression of Cre recombinase in transgenic mice. Genesis 26: 154-156.

Mangold, K.A., Takahashi, H., Brandigi, C., Wada, T., Wakui, S., Furusato, M., Boyd, J., Chandler, F.W., and Allsbrook, W.C., Jr. 1997. p16 (CDKN2/MTS1) gene deletions are rare in prostatic carcinomas in the United States and Japan. J. Urol. 157: 1117-1120.

Maroulakou, I.G., Anver, M., Garrett, L., and Green, J.E. 1994. Prostate and mammary adenocarcinoma in transgenic mice carrying a rat C3(1) simian virus 40 large tumor antigen fusion gene. Proc. Natl. Acad. Sci. 91: 11236-11240.

Matsushima, H., Kitamura, T., Goto, T., Hosaka, Y., Homma, Y., and Kawabe, K. 1997. Combined analysis with Bcl-2 and P53 immunostaining predicts poorer prognosis in prostatic carcinoma. J. Urol. 158: 2278-2283.

Matsuyama, H., Pan, Y., Skoog, L., Tribukait, B., Naito, K., Ekman, P., Lichter, P., and Bergerheim, U.S. 1994. Deletion mapping of chromosome $8 \mathrm{p}$ in prostate cancer by fluorescence in situ hybridization. Oncogene 9: 3071-3076.

Mawhinney, M.G. and Neubauer, B.L. 1979. Actions of estrogen in the male. Invest. Urol. 16: 409-420.

McDonnell, T.J., Navone, N.M., Troncoso, P., Pisters, L.L., Conti, C., von Eschenbach, A.C., Brisbay, S., and Logothetis, C.J. 1997. Expression of bcl-2 oncoprotein and p53 protein accumulation in bone marrow metastases of androgen independent prostate cancer. J. Urol. 157: 569-574.

McMenamin, M.E., Soung, P., Perera, S., Kaplan, I., Loda, M., and Sellers, W.R. 1999. Loss of PTEN expression in paraffinembedded primary prostate cancer correlates with high Gleason score and advanced stage. Cancer Res. 59: 42914296.

McNeal, J.E. 1969. Origin and development of carcinoma in the prostate. Cancer 23: 24-34.

McNeal, J.E. 1978. Origin and evolution of benign prostatic enlargement. Invest. Urol. 15: 340-345.

McNeal, J.E. 1988. Normal histology of the prostate. Am. J. Surg. Pathol. 12: 619-633.

McNeal, J.E. and Bostwick, D.G. 1986. Intraductal dysplasia: A premalignant lesion of the prostate. Hum. Pathol. 17: 64-71.

McWilliam, L.J., Manson, C., and George, N.J. 1997. Neuroendocrine differentiation and prognosis in prostatic adenocarcinoma. Brit. J. Urol. 80: 287-290.

Melamed, J., Einhorn, J.M., and Ittmann, M.M. 1997. Allelic loss on chromosome $13 \mathrm{q}$ in human prostate carcinoma. Clin Cancer Res. 3: 1867-1872.

Miller, G. 2000. Prostate cancer among the chinese: Pathologic, epidemiologic and nutritional considerations. In Advanced therapy of prostate disease (ed. M.I. Resnick and I.M. Thompson), pp. 18-27. B.C. Decker, London.

Miyake, H., Tolcher, A., and Gleave, M.E. 1999. Antisense Bcl-2 oligodeoxynucleotides inhibit progression to androgen- independence after castration in the Shionogi tumor model. Cancer Res. 59: 4030-4034.

Morton, R.A., Ewing, C.M., Nagafuchi, A., Tsukita, S., and Isaacs, W.B. 1993. Reduction of E-cadherin levels and deletion of the $\alpha$-catenin gene in human prostate cancer cells. Cancer Res. 53: 3585-3590.

Moul, J.W., Bettencourt, M.C., Sesterhenn, I.A., Mostofi, F.K., McLeod, D.G., Srivastava, S., and Bauer, J.J. 1996. Protein expression of p53, bcl-2, and KI-67 (MIB-1) as prognostic biomarkers in patients with surgically treated, clinically localized prostate cancer. Surgery 120: 159-166; discussion $166-157$.

Nagle, R.B., Ahmann, F.R., McDaniel, K.M., Paquin, M.L., Clark, V.A., and Celniker, A. 1987. Cytokeratin characterization of human prostatic carcinoma and its derived cell lines. Cancer Res. 47: 281-286.

Nagle, R.B., Brawer, M.K., Kittelson, J., and Clark, V. 1991. Phenotypic relationships of prostatic intraepithelial neoplasia to invasive prostatic carcinoma. Am. J. Pathol. 138: 119-128.

Nakayama, K., Ishida, N., Shirane, M., Inomata, A., Inoue, T., Shishido, N., Horii, I., and Loh, D.Y. 1996. Mice lacking p2 $7^{\text {(Kip1) }}$ display increased body size, multiple organ hyperplasia, retinal dysplasia, and pituitary tumors. Cell 85: 707720 .

Navone, N.M., Logothetis, C.J., von Eschenbach, A.C., and Troncoso, P. 1999. Model Systems of prostate cancer: Uses and limitations. Cancer Metastasis Rev. 17: 361-371.

Navone, N.M., Troncoso, P., Pisters, L.L., Goodrow, T.L., Palmer, J.L., Nichols, W.W., von Eschenbach, A.C., and Conti, C.J. 1993. p53 protein accumulation and gene mutation in the progression of human prostate carcinoma. J. Nat1. Cancer Inst. 85: 1657-1669.

Newmark, J.R., Hardy, D.O., Tonb, D.C., Carter, B.S., Epstein, J.I., Isaacs, W.B., Brown, T.R., and Barrack, E.R. 1992. Androgen receptor gene mutations in human prostate cancer. Proc. Natl. Acad. Sci. 89: 6319-6323.

Olumi, A.F., Grossfeld, G.D., Hayward, S.W., Carroll, P.R., Tlsty, T.D., and Cunha, G.R. 1999. Carcinoma-associated fibroblasts direct tumor progression of initiated human prostatic epithelium. Cancer Res. 59: 5002-5011.

Osman, I., Drobnjak, M., Fazzari, M., Ferrara, J., Scher, H.I., and Cordon-Cardo, C. 1999. Inactivation of the p53 pathway in prostate cancer: Impact on tumor progression. Clin. Cancer Res. 5: 2082-2088.

Otterson, G.A., Kratzke, R.A., Coxon, A., Kim, Y.W., and Kaye, F.J. 1994. Absence of $\mathrm{p} 16^{\mathrm{INK} 4}$ protein is restricted to the subset of lung cancer lines that retains wildtype $R B$. Oncogene 9: 3375-3378.

Park, D.J., Wilczynski, S.P., Pham, E.Y., Miller, C.W., and Koeffler, H.P. 1997. Molecular analysis of the INK4 family of genes in prostate carcinomas. J. Urol. 157: 1995-1999.

Park, M.S., Rosai, J., Nguyen, H.T., Capodieci, P., CordonCardo, C., and Koff, A. 1999. p27 and Rb are on overlapping pathways suppressing tumorigenesis in mice. Proc. Natl. Acad. Sci. 96: 6382-6387.

Perez-Stable, C., Altman, N.H., Mehta, P.P., Deftos, L.J., and Roos, B.A. 1997. Prostate cancer progression, metastasis, and gene expression in transgenic mice. Cancer Res. 57:900- 
906.

Pesche, S., Latil, A., Muzeau, F., Cussenot, O., Fournier, G., Longy, M., Eng, C., and Lidereau, R. 1998. PTEN/MMAC1/ TEP1 involvement in primary prostate cancers. Oncogene 16: $2879-2883$.

Phillips, S.M., Barton, C.M., Lee, S.J., Morton, D.G., Wallace, D.M., Lemoine, N.R., and Neoptolemos, J.P. 1994. Loss of the retinoblastoma susceptibility gene $(R B 1)$ is a frequent and early event in prostatic tumorigenesis. Brit. J. Cancer 70: $1252-1257$.

Pietenpol, J.A., Bohlander, S.K., Sato, Y., Papadopoulos, N., Liu, B., Friedman, C., Trask, B.J., Roberts, J.M., Kinzler, K.W., Rowley, J.D., et al. 1995. Assignment of the human $p 27^{\text {Kip } 1}$ gene to $12 \mathrm{p} 13$ and its analysis in leukemias. Cancer Res. 55: $1206-1210$.

Pilat, M.J.P., Kamdradt, J.M., and Pienta, K.J. 1999. Hormone resistance in prostate cancer. Cancer Metastasis Rev. 17: 373-381.

Pisters, L.L., Troncoso, P., Zhau, H.E., Li, W., von Eschenbach, A.C., and Chung, L.W. 1995. c-met proto-oncogene expression in benign and malignant human prostate tissues. I. Urol. 154: 293-298.

Podlasek, C.A., Barnett, D.H., Clemens, J.Q., Bak, P.M., and Bushman, W. 1999. Prostate development requires Sonic hedgehog expressed by the urogenital sinus epithelium. Dev. Biol. 209: 28-39.

Podlasek, C.A., Duboule, D., and Bushman, W. 1997. Male accessory sex organ morphogenesis is altered by loss of function of Hoxd-13. Dev. Dyn. 208: 454-465.

Podsypanina, K., Ellenson, L.H., Nemes, A., Gu, J., Tamura, M., Yamada, K.M., Cordon-Cardo, C., Catoretti, G., Fisher, P.E., and Parsons, R. 1999. Mutation of Pten/Mmac1 in mice causes neoplasia in multiple organ systems. Proc. Natl. Acad. Sci. 96: 1563-1568.

Ponce-Castaneda, M.V., Lee, M.H., Latres, E., Polyak, K., Lacombe, L., Montgomery, K., Mathew, S., Krauter, K., Sheinfeld, J., Massague, J., et al. 1995. p2 $7^{\text {Kip } 1}$ : Chromosomal mapping to 12 p12-12p13.1 and absence of mutations in human tumors. Cancer Res. 55: 1211-1214.

Prehn, R.T. 1999. On the prevention and therapy of prostate cancer by androgen administration. Cancer Res. 59: 41614164.

Prendergast, N.J., Atkins, M.R., Schatte, E.C., Paulson, D.F., and Walther, P.J. 1996. p53 immunohistochemical and genetic alterations are associated at high incidence with postirradiated locally persistent prostate carcinoma. I. Urol. 155: 1685-1692.

Prochownik, E.V., Eagle Grove, L., Deubler, D., Zhu, X.L., Stephenson, R.A., Rohr, L.R., Yin, X., and Brothman, A.R. 1998. Commonly occurring loss and mutation of the MXI1 gene in prostate cancer. Genes Chromosomes Cancer 22: 295-304.

Qian, J., Bostwick, D.G., Takahashi, S., Borell, T.J., Herath, J.F., Lieber, M.M., and Jenkins, R.B. 1995. Chromosomal anomalies in prostatic intraepithelial neoplasia and carcinoma detected by fluorescence in situ hybridization. Cancer Res. 55: 5408-5414.

Raffo, A.J., Perlman, H., Chen, M.W., Day, M.L., Streitman, J.S., and Buttyan, R. 1995. Overexpression of bcl-2 protects prostate cancer cells from apoptosis in vitro and confers resistance to androgen depletion in vivo. Cancer Res. 55: 44384445.

Reiter, R.E., Gu, Z., Watabe, T., Thomas, G., Szigeti, K., Davis, E., Wahl, M., Nisitani, S., Yamashiro, J., Le Beau, M.M., et al. 1998. Prostate stem cell antigen: A cell surface marker overexpressed in prostate cancer. Proc. Natl. Acad. Sci. 95: 17351740.
Rinker-Schaeffer, C.W., Hawkins, A.L., Ru, N., Dong, J., Stoica, G., Griffin, C.A., Ichikawa, T., Barrett, J.C., and Isaacs, J.T. 1994. Differential suppression of mammary and prostate cancer metastasis by human chromosomes 17 and 11. Cancer Res. 54: 6249-6256.

Ruizeveld de Winter, J.A., Janssen, P.J., Sleddens, H.M., Verleun-Mooijman, M.C., Trapman, J., Brinkmann, A.O., Santerse, A.B., Schroder, F.H., and van der Kwast, T.H. 1994 Androgen receptor status in localized and locally progressive hormone refractory human prostate cancer. Am. J. Pathol. 144: 735-746.

Sakr, W.A., Haas, G.P., Cassin, B.F., Pontes, J.E., and Crissman, J.D. 1993. The frequency of carcinoma and intraepithelial neoplasia of the prostate in young male patients. I. Urol. 150: 379-385.

Sakr, W.A., Macoska, J.A., Benson, P., Grignon, D.J., Wolman, S.R., Pontes, J.E., and Crissman, J.D. 1994. Allelic loss in locally metastatic, multisampled prostate cancer. Cancer Res. 54: 3273-3277.

Saric, T., Brkanac, Z., Troyer, D.A., Padalecki, S.S., Sarosdy, M., Williams, K., Abadesco, L., Leach, R.J., and O'Connell, P. 1999. Genetic pattern of prostate cancer progression. Int. J. Cancer 81: 219-224.

Sarkar, F.H., Li, Y., Sakr, W.A., Grignon, D.J., Madan, S.S., Wood, D.P., Jr., and Adsay, V. 1999. Relationship of p21 (WAF1) expression with disease-free survival and biochemical recurrence in prostate adenocarcinomas (PCa). Prostate 40: $256-260$.

Sarkar, F.H., Sakr, W., Li, Y.W., Macoska, J., Ball, D.E., and Crissman, J.D. 1992. Analysis of retinoblastoma $(R B)$ gene deletion in human prostatic carcinomas. Prostate 21: 145152.

Schaffner, D.L., Barrios, R., Shaker, M.R., Rajagopalan, S., Huang, S.L., Tindall, D.J., Young, C.Y., Overbeek, P.A., Lebovitz, R.M., and Lieberman, M.W. 1995. Transgenic mice carrying a PSArasT24 hybrid gene develop salivary gland and gastrointestinal tract neoplasms. Lab. Invest. 72: 283-290.

Schreiber-Agus, N., Meng, Y., Hoang, T., Hou, H., Jr., Chen, K., Greenberg, R., Cordon-Cardo, C., Lee, H.W., and DePinho, R.A. 1998. Role of Mxil in ageing organ systems and the regulation of normal and neoplastic growth. Nature 393: 483-487.

Sciavolino, P.J., Abrams, E.W., Yang, L., Austenberg, L.P., Shen, M.M., and Abate-Shen, C. 1997. Tissue-specific expression of murine Nkx3.1 in the male urogenital system. Dev. Dyn. 209: $127-138$.

Sherwood, E.R., Berg, L.A., Mitchell, N.J., McNeal, J.E., Kozlowski, J.M., and Lee, C. 1990. Differential cytokeratin expression in normal, hyperplastic and malignant epithelial cells from human prostate. J. Urol. 143: 167-171.

Shibata, M.A., Ward, J.M., Devor, D.E., Liu, M.L., and Green, J.E. 1996. Progression of prostatic intraepithelial neoplasia to invasive carcinoma in C3(1)/SV40 large T antigen transgenic mice: Histopathological and molecular biological alterations. Cancer Res. 56: 4894-4903.

Shurbaji, M.S., Kalbfleisch, J.H., and Thurmond, T.S. 1995. Immunohistochemical detection of p53 protein as a prognostic indicator in prostate cancer. Hum. Pathol. 26: 106-109.

Singh, S.P., Lipman, J., Goldman, H., Ellis, F.H., Jr., Aizenman, L., Cangi, M.G., Signoretti, S., Chiaur, D.S., Pagano, M., and Loda, M. 1998. Loss or altered subcellular localization of p27 in Barrett's associated adenocarcinoma. Cancer Res. 58: $1730-1735$.

Skalnik, D.G., Dorfman, D.M., Williams, D.A., and Orkin, S.H. 1991. Restriction of neuroblastoma to the prostate gland in transgenic mice. Mol. Cell Biol. 11: 4518-4527. 
Smith, J.R., Freije, D., Carpten, J.D., Gronberg, H., Xu, J., Isaacs, S.D., Brownstein, M.J., Bova, G.S., Guo, H., Bujnovszky, P., et al. 1996. Major susceptibility locus for prostate cancer on chromosome 1 suggested by a genome-wide search. Science 274: $1371-1374$

Sommerfeld, H.J., Meeker, A.K., Piatyszek, M.A., Bova, G.S., Shay, J.W., and Coffey, D.S. 1996. Telomerase activity: A prevalent marker of malignant human prostate tissue. Cancer Res. 56: 218-222.

Stackhouse, G.B., Sesterhenn, I.A., Bauer, J.J., Mostofi, F.K., Connelly, R.R., Srivastava, S.K., and Moul, J.W. 1999. p53 and bcl-2 immunohistochemistry in pretreatment prostate needle biopsies to predict recurrence of prostate cancer after radical prostatectomy. J. Urol. 162: 2040-2045.

Steck, P.A., Pershouse, M.A., Jasser, S.A., Yung, W.K., Lin, H., Ligon, A.H., Langford, L.A., Baumgard, M.L., Hattier, T., Davis, T., et al. 1997. Identification of a candidate tumour suppressor gene, MMAC1, at chromosome 10q23.3 that is mutated in multiple advanced cancers. Nat. Genet. 15: 356362 .

Sugimura, Y., Cunha, G.R., and Donjacour, A.A. 1986. Morphogenesis of ductal networks in the mouse prostate. Biol. Reprod. 34: 961-971.

Sun, H., Lesche, R., Li, D.M., Liliental, J., Zhang, H., Gao, J., Gavrilova, N., Mueller, B., Liu, X., and Wu, H. 1999. PTEN modulates cell cycle progression and cell survival by regulating phosphatidylinositol 3,4,5,-trisphosphate and Akt/ protein kinase B signaling pathway. Proc. Natl. Acad. Sci. 96: 6199-6204.

Suzuki, A., de la Pompa, J.L., Stambolic, V., Elia, A.J., Sasaki, T., del Barco Barrantes, I., Ho, A., Wakeham, A., Itie, A., Khoo, W., et al. 1998a. High cancer susceptibility and embryonic lethality associated with mutation of the PTEN tumor suppressor gene in mice. Curr. Biol. 8: 1169-1178.

Suzuki, H., Emi, M., Komiya, A., Fujiwara, Y., Yatani, R., Nakamura, Y., and Shimazaki, J. 1995. Localization of a tumor suppressor gene associated with progression of human prostate cancer within a $1.2 \mathrm{Mb}$ region of $8 \mathrm{p} 22-\mathrm{p} 21.3$. Genes Chromosomes Cancer 13: 168-174.

Suzuki, H., Freije, D., Nusskern, D.R., Okami, K., Cairns, P., Sidransky, D., Isaacs, W.B., and Bova, G.S. 1998b. Interfocal heterogeneity of PTEN/MMAC1 gene alterations in multiple metastatic prostate cancer tissues. Cancer Res. 58: 204-209.

Sweat, S.D., Pacelli, A., Bergstralh, E.J., Slezak, J.M., and Bostwick, D.G. 1999. Androgen receptor expression in prostatic intraepithelial neoplasia and cancer. J. Urol. 161: 12291232.

Takahashi, S., Shan, A.L., Ritland, S.R., Delacey, K.A., Bostwick, D.G., Lieber, M.M., Thibodeau, S.N., and Jenkins, R.B. 1995. Frequent loss of heterozygosity at 7q31.1 in primary prostate cancer is associated with tumor aggressiveness and progression. Cancer Res. 55: 4114-4119.

Tamimi, Y., Bringuier, P.P., Smit, F., van Bokhoven, A., Debruyne, F.M., and Schalken, J.A. 1996. p16 mutations/deletions are not frequent events in prostate cancer. Brit. J. Cancer 74: 120-122.

Tan, P., Cady, B., Wanner, M., Worland, P., Cukor, B., MagiGalluzzi, C., Lavin, P., Draetta, G., Pagano, M., and Loda, M. 1997. The cell cycle inhibitor p27 is an independent prognostic marker in small (Tla,b) invasive breast carcinomas. Cancer Res. 57: 1259-1263.

Taplin, M.E., Bubley, G.J., Shuster, T.D., Frantz, M.E., Spooner, A.E., Ogata, G.K., Keer, H.N., and Balk, S.P. 1995. Mutation of the androgen-receptor gene in metastatic androgen-independent prostate cancer. New Engl. J. Med. 332: 1393-1398.

Tavassoli, F.A. 1998. Ductal carcinoma in situ: Introduction of the concept of ductal intraepithelial neoplasia. Mod. Pathol. 11: $140-154$

Thalmann, G.N., Anezinis, P.E., Chang, S.M., Zhau, H.E., Kim, E.E., Hopwood, V.L., Pathak, S., von Eschenbach, A.C., and Chung, L.W. 1994. Androgen-independent cancer progression and bone metastasis in the LNCaP model of human prostate cancer. Cancer Res. 54: 2577-2581; erratum 3953.

Theodorescu, D., Broder, S.R., Boyd, J.C., Mills, S.E., and Frierson, H.F., Jr. 1997. p53, bcl-2 and retinoblastoma proteins as long-term prognostic markers in localized carcinoma of the prostate. J. Urol. 158: 131-137.

Thiessen, E.U. 1974. Concerning a familial association between breast cancer and both prostatic and uterine malignancies. Cancer 34: 1102-1107.

Thomas, D.J., Robinson, M., King, P., Hasan, T., Charlton, R., Martin, J., Carr, T.W., and Neal, D.E. 1993. p53 expression and clinical outcome in prostate cancer. Brit. I. Urol. 72: 778-781.

Thompson, T.C., Southgate, J., Kitchener, G., and Land, H. 1989. Multistage carcinogenesis induced by ras and myc oncogenes in a reconstituted organ. Cell 56: 917-930.

Tilley, W.D., Buchanan, G., Hickey, T.E., and Bentel, J.M. 1996. Mutations in the androgen receptor gene are associated with progression of human prostate cancer to androgen independence. Clin. Cancer Res. 2: 277-285.

Tilley, W.D., Wilson, C.M., Marcelli, M., and McPhaul, M.J. 1990. Androgen receptor gene expression in human prostate carcinoma cell lines. Cancer Res. 50: 5382-5386.

Timms, B.G., Mohs, T.J., and Didio, L.J. 1994. Ductal budding and branching patterns in the developing prostate. J. Urol. 151: $1427-1432$.

Totten, R.S., Heinman, M.W., Hudson, P.B., Sproul, E.E., and Stout, A.P. 1953. Microscopic differential diagnosis of latent carcinoma of the prostate. Arch. Pathol. 55: 131-141.

Trapman, J., Ris-Stalpers, C., van der Korput, J.A., Kuiper, G.G., Faber, P.W., Romijn, J.C., Mulder, E., and Brinkmann, A.O. 1990. The androgen receptor: Functional structure and expression in transplanted human prostate tumors and prostate tumor cell lines. J. Steroid Biochem. Mol. Biol. 37: 837842.

Trapman, J., Sleddens, H.F., van der Weiden, M.M., Dinjens, W.N., Konig, J.J., Schroder, F.H., Faber, P.W., and Bosman, F.T. 1994. Loss of heterozygosity of chromosome 8 microsatellite loci implicates a candidate tumor suppressor gene between the loci D8S87 and D8S133 in human prostate cancer. Cancer Res. 54: 6061-6064.

Trybus, T.M., Burgess, A.C., Wojno, K.J., Glover, T.W., and Macoska, J.A. 1996. Distinct areas of allelic loss on chromosomal regions 10p and 10q in human prostate cancer. Cancer Res. 56: 2263-2267.

Tsihlias, J., Kapusta, L., and Slingerland, J. 1999. The prognostic significance of altered cyclin-dependent kinase inhibitors in human cancer. Annu. Rev. Med. 50: 401-423.

Tsihlias, J., Kapusta, L.R., DeBoer, G., Morava-Protzner, I., Zbieranowski, I., Bhattacharya, N., Catzavelos, G.C., Klotz, L.H., and Slingerland, J.M. 1998. Loss of cyclin-dependent kinase inhibitor $\mathrm{p} 27^{\mathrm{Kip} 1}$ is a novel prognostic factor in localized human prostate adenocarcinoma. Cancer Res. 58: 542548

Tu, S.M., McConnell, K., Marin, M.C., Campbell, M.L., Fernandez, A., von Eschenbach, A.C., and McDonnell, T.J. 1995. Combination adriamycin and suramin induces apoptosis in bcl-2 expressing prostate carcinoma cells. Cancer Lett. 93: $147-155$.

Tulinius, H., Egilsson, V., Olafsdottir, G.H., and Sigvaldason, H. 1992. Risk of prostate, ovarian, and endometrial cancer 
among relatives of women with breast cancer. BMJ 305: 855 857.

Ueki, K., Ono, Y., Henson, J.W., Efird, J.T., von Deimling, A., and Louis, D.N. 1996. CDKN2/p16 or RB alterations occur in the majority of glioblastomas and are inversely correlated. Cancer Res. 56: 150-153.

Umbas, R., Isaacs, W.B., Bringuier, P.P., Schaafsma, H.E., Karthaus, H.F., Oosterhof, G.O., Debruyne, F.M., and Schalken, J.A. 1994. Decreased E-cadherin expression is associated with poor prognosis in patients with prostate cancer. Cancer Res. 54: 3929-3933.

Umbas, R., Schalken, J.A., Aalders, T.W., Carter, B.S., Karthaus, H.F., Schaafsma, H.E., Debruyne, F.M., and Isaacs, W.B. 1992. Expression of the cellular adhesion molecule E-cadherin is reduced or absent in high-grade prostate cancer. Cancer Res. 52: 5104-5109.

Van Den Berg, C., Guan, X.-Y., Von Hoff, D., Jenkins, R., Bittner, M., Griffin, C., Kallioniemi, O., Visakorpi, T., McGill, J., Herath, J., et al. 1995. DNA sequence amplification in human prostate cancer identified by chromosome microdissection: Potential prognostic implications. Clin. Cancer Res. 1: $11-18$.

van der Kwast, T.H., Schalken, J., Ruizeveld de Winter, J.A., van Vroonhoven, C.C., Mulder, E., Boersma, W., and Trapman, J. 1991. Androgen receptors in endocrine-therapy-resistant human prostate cancer. Int1. J. Cancer 48: 189-193.

Veldscholte, J., Berrevoets, C.A., Ris-Stalpers, C., Kuiper, G.G., Jenster, G., Trapman, J., Brinkmann, A.O., and Mulder, E. 1992. The androgen receptor in LNCaP cells contains a mutation in the ligand binding domain which affects steroid binding characteristics and response to antiandrogens. J. Steroid Biochem. Mol. Biol. 41: 665-669.

Verhagen, A.P., Aalders, T.W., Ramaekers, F.C., Debruyne, F.M., and Schalken, J.A. 1988. Differential expression of keratins in the basal and luminal compartments of rat prostatic epithelium during degeneration and regeneration. Prostate 13: 25-38.

Verhagen, A.P., Ramaekers, F.C., Aalders, T.W., Schaafsma, H.E., Debruyne, F.M., and Schalken, J.A. 1992. Colocalization of basal and luminal cell-type cytokeratins in human prostate cancer. Cancer Res. 52: 6182-6187.

Visakorpi, T., Hyytinen, E., Koivisto, P., Tanner, M., Keinanen, R., Palmberg, C., Palotie, A., Tammela, T., Isola, J., and Kallioniemi, O.P. 1995a. In vivo amplification of the androgen receptor gene and progression of human prostate cancer. Nat. Genet. 9: 401-406.

Visakorpi, T., Kallioniemi, A.H., Syvanen, A.C., Hyytinen, E.R., Karhu, R., Tammela, T., Isola, J.J., and Kallioniemi, O.P. 1995b. Genetic changes in primary and recurrent prostate cancer by comparative genomic hybridization. Cancer Res. 55: 342-347.

Visakorpi, T., Kallioniemi, O.P., Heikkinen, A., Koivula, T., and Isola, J. 1992. Small subgroup of aggressive, highly proliferative prostatic carcinomas defined by p53 accumulation. $J$. Natl. Cancer Inst. 84: 883-887.

Vlietstra, R.J., van Alewijk, D.C., Hermans, K.G., van Steenbrugge, G.J., and Trapman, J. 1998. Frequent inactivation of PTEN in prostate cancer cell lines and xenografts. Cancer Res. 58: 2720-2723.

Vocke, C.D., Pozzatti, R.O., Bostwick, D.G., Florence, C.D., Jennings, S.B., Strup, S.E., Duray, P.H., Liotta, L.A., EmmertBuck, M.R., and Linehan, W.M. 1996. Analysis of 99 microdissected prostate carcinomas reveals a high frequency of allelic loss on chromosome 8p12-21. Cancer Res. 56: 24112416.

Voeller, H.J., Augustus, M., Madike, V., Bova, G.S., Carter, K.C., and Gelmann, E.P. 1997. Coding region of NKX3.1, a prostate-specific homeobox gene on 8 p21, is not mutated in human prostate cancers. Cancer Res. 57: 4455-4459.

Voeller, H.J., Sugars, L.Y., Pretlow, T., and Gelmann, E.P. 1994. p53 oncogene mutations in human prostate cancer specimens. J. Urol. 151: 492-495.

Wang, S.I., Parsons, R., and Ittmann, M. 1998. Homozygous deletion of the PTEN tumor suppressor gene in a subset of prostate adenocarcinomas. Clin. Cancer. Res. 4: 811-815.

Wang, Y., Hayward, S.W., Donjacour, A.A., Young, P., Jacks, T., Sage, J., Dahiya, R., Cardiff, R.D., Day, M.L., et al. 2000. The role of $R b$ in sex hormone induced prostatic carcinogenesis. Cancer Res. (in press).

Wang, Y.Z. and Wong, Y.C. 1998. Sex hormone-induced prostatic carcinogenesis in the Noble rat: The role of insulin-like growth factor-I (IGF-I) and vascular endothelial growth factor (VEGF) in the development of prostate cancer. Prostate 35: $165-177$.

Waters, D.J., Sakr, W.A., Hayden, D.W., Lang, C.M., McKinney, L., Murphy, G.P., Radinsky, R., Ramoner, R., Richardson, R.C., and Tindall, D.J. 1998. Workgroup 4: Spontaneous prostate carcinoma in dogs and nonhuman primates. Prostate 36: 64-67.

Weinstein, M.H., Partin, A.W., Veltri, R.W., and Epstein, J.I. 1996. Neuroendocrine differentiation in prostate cancer: Enhanced prediction of progression after radical prostatectomy. Hum. Pathol. 27: 683-687.

Whang, Y.E., Wu, X., Suzuki, H., Reiter, R.E., Tran, C., Vessella, R.L., Said, J.W., Isaacs, W.B., and Sawyers, C.L. 1998. Inactivation of the tumor suppressor PTEN/MMAC1 in advanced human prostate cancer through loss of expression. Proc. Nat1. Acad. Sci. 95: 5246-5250.

Wieland, I., Arden, K.C., Michels, D., Klein-Hitpass, L., Bohm, M., Viars, C.S., and Weidle, U.H. 1999. Isolation of DICE1: A gene frequently affected by $\mathrm{LOH}$ and downregulated in lung carcinomas. Oncogene 18: 4530-4537.

Wistuba, I.I., Behrens, C., Virmani, A.K., Milchgrub, S., Syed, S., Lam, S., Mackay, B., Minna, J.D., and Gazdar, A.F. 1999. Allelic losses at chromosome 8p21-23 are early and frequent events in the pathogenesis of lung cancer. Cancer Res. 59: 1973-1979.

Wu, H.C., Hsieh, J.T., Gleave, M.E., Brown, N.M., Pathak, S., and Chung, L.W. 1994. Derivation of androgen-independent human LNCaP prostatic cancer cell sublines: Role of bone stromal cells. Intl. J. Cancer 57: 406-412.

Wu, X., Senechal, K., Neshat, M.S., Whang, Y.E., and Sawyers, C.L. 1998. The PTEN/MMAC1 tumor suppressor phosphatase functions as a negative regulator of the phosphoinositide 3-kinase/Akt pathway. Proc. Natl. Acad. Sci. 95: 1558715591.

Xu, J., Meyers, D., Freije, D., Isaacs, S., Wiley, K., Nusskern, D., Ewing, C., Wilkens, E., Bujnovszky, P., Bova, G.S., et al. 1998. Evidence for a prostate cancer susceptibility locus on the X chromosome. Nat. Genet. 20: 175-179.

Xu, L.L., Srikantan, V., Sesterhenn, I.A., Augustus, M., Dean, R., Moul, J.W., Carter, K.C., and Srivastava, S. 2000. Expression profile of an androgen regulated prostate specific homeobox gene NKX3.1 in primary prostate cancer. J. Urol. 163: 972979.

Yan, Y., Sheppard, P.C., Kasper, S., Lin, L., Hoare, S., Kapoor, A., Dodd, J.G., Duckworth, M.L., and Matusik, R.J. 1997. Large fragment of the probasin promoter targets high levels of transgene expression to the prostate of transgenic mice. Prostate 32: 129-139.

Yang, G., Stapleton, A.M., Wheeler, T.M., Truong, L.D., Timme, T.L., Scardino, P.T., and Thompson, T.C. 1996. 
Clustered p53 immunostaining: A novel pattern associated with prostate cancer progression. Clin. Cancer Res. 2: 399401.

Yang, R.M., Naitoh, J., Murphy, M., Wang, H.J., Phillipson, J., deKernion, J.B., Loda, M., and Reiter, R.E. 1998. Low p27 expression predicts poor disease-free survival in patients with prostate cancer. J. Urol. 159: 941-945.

Yeh, S., Miyamoto, H., Nishimura, K., Kang, H., Ludlow, J., Hsiao, P., Wang, C., Su, C., and Chang, C. 1998. Retinoblastoma, a tumor suppressor, is a coactivator for the androgen receptor in human prostate cancer DU145 cells. Biochem. Biophys. Res. Commun. 248: 361-367.

Zenklusen, J.C., Thompson, J.C., Troncoso, P., Kagan, J., and Conti, C.J. 1994. Loss of heterozygosity in human primary prostate carcinomas: A possible tumor suppressor gene at 7q31.1. Cancer Res. 54: 6370-6373.

Zhang, W., Kapusta, L.R., Slingerland, J.M., and Klotz, L.H. 1998. Telomerase activity in prostate cancer, prostatic intraepithelial neoplasia, and benign prostatic epithelium. Cancer Res. 58: 619-621.

Zhang, X., Chen, M.W., Ng, A., Ng, P.Y., Lee, C., Rubin, M., Olsson, C.A., and Buttyan, R. 1997. Abnormal prostate development in C3(1)-bcl-2 transgenic mice. Prostate 32: 1626.

Zhao, X., Gschwend, J.E., Powell, C.T., Foster, R.G., Day, K.C., and Day, M.L. 1997. Retinoblastoma protein-dependent growth signal conflict and caspase activity are required for protein kinase C-signaled apoptosis of prostate epithelial cells. J. Biol. Chem. 272: 22751-22757. 


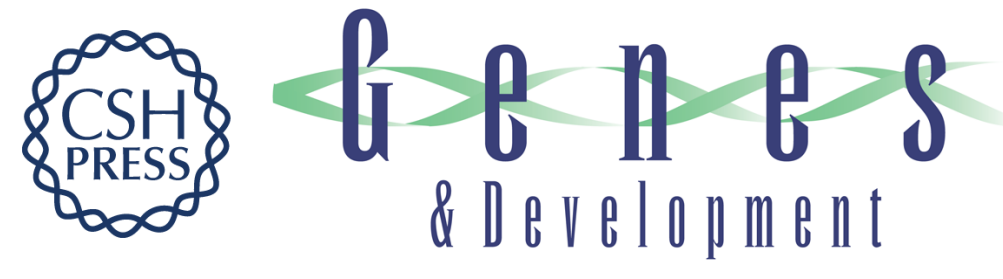

\section{Molecular genetics of prostate cancer}

Cory Abate-Shen and Michael M. Shen

Genes Dev. 2000, 14:

Access the most recent version at doi:10.1101/gad.819500

References This article cites 300 articles, 114 of which can be accessed free at: http://genesdev.cshlp.org/content/14/19/2410.full.html\#ref-list-1

License

Email Alerting Receive free email alerts when new articles cite this article - sign up in the box at the top Service right corner of the article or click here.

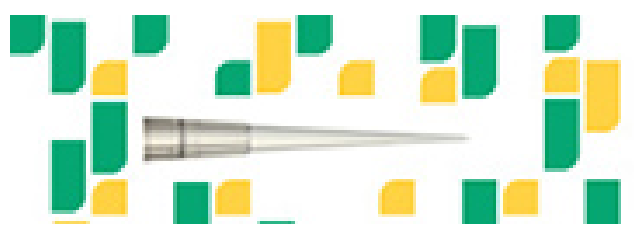

Focused on your science. 